\title{
Review \\ Priming for Life: Early Life Nutrition and the Microbiota-Gut-Brain Axis
}

\author{
Anna Ratsika ${ }^{1,2}$, Martin C. Codagnone ${ }^{1,2}$, Siobhain $\mathrm{O}^{\prime}$ Mahony ${ }^{1,2}$, Catherine Stanton ${ }^{1,3,4}$ and John F. Cryan ${ }^{1,2, *}$ \\ 1 APC Microbiome Ireland, Biosciences Institute, University College Cork, Cork T12 YT20, Ireland; \\ anna.ratsika@ucc.ie (A.R.); martin.codagnone@ucc.ie (M.C.C.); somahony@ucc.ie (S.O.); \\ catherine.stanton@teagasc.ie (C.S.) \\ 2 Department of Anatomy and Neuroscience, University College Cork, Cork T12 YT20, Ireland \\ 3 Department of Psychiatry and Neurobehavioural Science, University College Cork, Cork T12 YT20, Ireland \\ 4 Teagasc Food Research Centre, Moorepark, Fermoy P61 C996, Ireland \\ * Correspondence: j.cryan@ucc.ie
}

Citation: Ratsika, A.; Codagnone, M.C; O'Mahony, S.; Stanton, C.; Cryan, J.F Priming for Life: Early Life Nutrition and the

Microbiota-Gut-Brain Axis. Nutrients 2021, 13, 423. https://doi.org/ $10.3390 /$ nu13020423

Academic Editor: Cristina Campoy Received: 20 December 2020

Accepted: 24 January 2021

Published: 28 January 2021

Publisher's Note: MDPI stays neutral with regard to jurisdictional claims in published maps and institutional affiliations.

Copyright: (c) 2021 by the authors. Licensee MDPI, Basel, Switzerland. This article is an open access article distributed under the terms and conditions of the Creative Commons Attribution (CC BY) license (https:// creativecommons.org/licenses/by/ $4.0 /)$.

\begin{abstract}
Microbes colonize the human body during the first moments of life and coexist with the host throughout the lifespan. Intestinal microbiota and their metabolites aid in the programming of important bodily systems such as the immune and the central nervous system during critical temporal windows of development, with possible structural and functional implications throughout the lifespan. These critical developmental windows perinatally (during the first 1000 days) are susceptible timepoints for insults that can endure long lasting effects on the microbiota-gut-brain axis. Environmental and parental factors like host genetics, mental health, nutrition, delivery and feeding mode, exposure to antibiotics, immune activation and microbiota composition antenatally, are all factors that are able to modulate the microbiota composition of mother and infant and may thus regulate important bodily functions. Among all these factors, early life nutrition plays a pivotal role in perinatal programming and in the modulation of offspring microbiota from birth throughout lifespan. This review aims to present current data on the impact of early life nutrition and microbiota priming of important bodily systems and all the factors influencing the microbial coexistence with the host during early life development.
\end{abstract}

Keywords: nutrition; early life; microbiota-gut-brain axis; brain development; breast milk; infant formula

\section{Introduction}

Starting from the first moments of life, the human body is colonized by a wide variety of microorganisms [1,2] that coexist with the host for mutual beneficial purposes [3]. These microorganisms colonize the skin and various mucosal cavities (oral, nasal, vaginal and pulmonary), yet the vast majority of them are located within the gastrointestinal (GI) tract and are termed as the intestinal microbiota [4]. The composition of the intestinal microbiota is believed to largely assemble after birth influenced by early life events such as delivery mode [1], early life nutrition [5], and antibiotic exposure [6]. The microbiota continues to expand and develop in accordance with the needs of the host across the lifespan.

The microbiota has been found to influence not only at a local level with respect to the intestinal microenvironment but also beyond the GI tract, implicating the physiological and structural aspects of the central nervous system (CNS). The communication pathways which enable the interaction of intestinal microbiota with the CNS of the host is described as the microbiota-gut-brain axis [7-10]. Although the gut-brain axis was initially a target for research on hunger, satiety and digestion $[11,12]$ most recent studies have focused on cognition and behaviour; the impact of psychological stress on GI motility, permeability and secretion, as well as the effect of afferent neuronal fibre stimulation in the gut on certain psychopathologies $[7,13]$. The pathways of the gut-brain axis have emerged as 
novel targets for mental health conditions, as well as for obesity and GI disorders including irritable bowel syndrome (IBS) $[9,14,15]$.

To date, the majority of data on the microbiota-gut-brain axis has been gathered from studies using animal model systems. Indeed, various germ-free (GF) animal studies have shown that lifelong absence of microbiota not only alters gut physiological functions, but also the behaviour of those animals [16-18]. Similar findings are now appreciated regarding the effects of antibiotic-induced microbiota depletion on intestinal permeability, behaviour and cognitive functions [19-21]. There are increasing studies in humans, both in early life and throughout the lifespan validating such findings [9,22-24].

Despite intensive investigations, the mechanisms underlying the communication pathways between intestinal microbial systems and the host remains rather elusive. Moreover, the full implication of such interactions on health and disease in critical temporal windows across the lifespan are still being unravelled. The impact of early life nutrition on the composition of the gut microbiota, the microbiota-mediated priming of CNS and immune system and the response of the host during this crosstalk is intricate and complex. The aim of this review is to summarize recent knowledge and highlight the effects of early life nutrition on the gut-brain axis development, the shaping and maturation of the intestinal microbiota and the dialogue among these stakeholders during critical periods of neurodevelopment.

\subsection{Disruption of the Microbiota-Gut Brain Axis}

Homeostasis of the intestinal microbial environment is likely to be affected multiple times across the lifespan of the average individual due to antibiotic usage [25], inflammation [26], ageing [27], psychological stress [28], nutrition and lifestyle choices [29], as well as other environmental factors (i.e., smoking, pollution, mode of birth) [1,30-33] (see Figure 1). Early life modulation and priming of the microbiota has been found to influence brain health and disease state later in life [34]. For instance, alterations in bacterial composition in the gut during early life have been correlated with behaviours associated with autism spectrum disorder [35-37]. Moreover, gut microbiota perturbations (i.e., via antibiotic exposure) in early life has been associated with a higher risk of mental illness such as anxiety and depression in humans [38], among others [39]. However, there are also epidemiological studies showing limited effects of antibiotic exposure in early life on mental health outcomes [40] indicating there is more at play than just altered composition of the microbiota.

Early life factors influencing the congnitive and microbiota development of the child

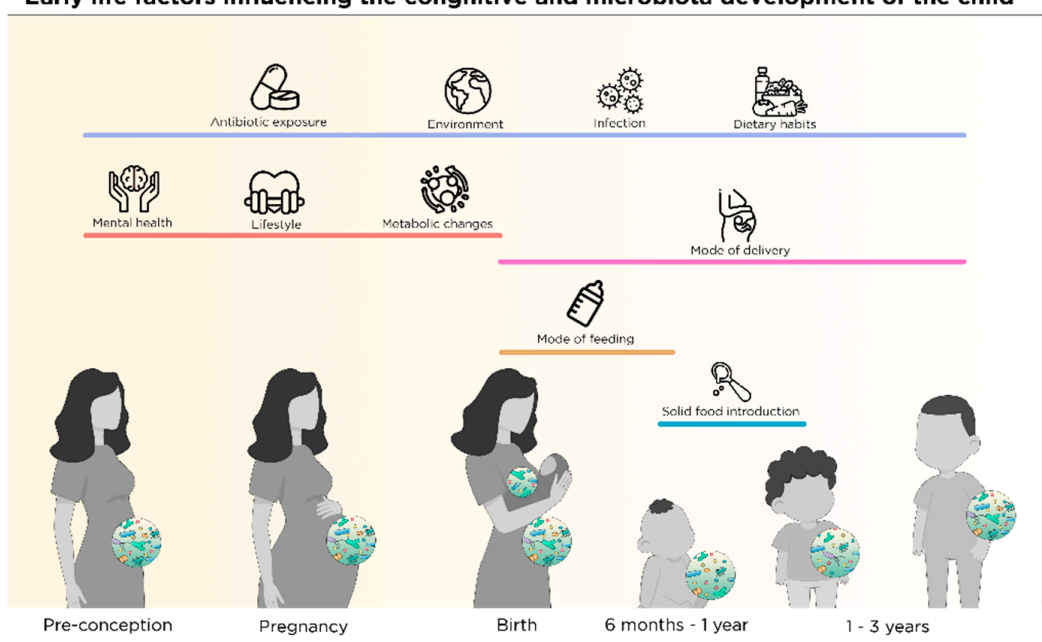

Figure 1. Early life factors influencing cognitive and microbial development of the child from preconception throughout the first 3 years of life; maternal mental health, lifestyle and metabolic changes affect fetal development. Antibiotic use, infections, environment, dietary habits and mode of delivery impacts the maternal health status, the fetal development during pregnancy and the microbiota 
and cognitive development of children from birth to at least 3 years. Mode of feeding in early life and solid food introduction influence the microbial and cognitive development of the offspring from birth up to at least 3 years of age.

Despite the underlying mechanisms of the intercommunication along the microbiotagut-brain axis remain incompletely understood, there is a variety of potential trajectories (some of which are depicted in Figure 2) through which the intestinal microbiota may influence the CNS [41,42]. Pathways associated with the reciprocal exchange of signals from brain and microbiota include the vagus nerve, the hypothalamic-pituitary-adrenal (HPA) axis, the immune system, as well as neurotransmitters and metabolites with neuroactive properties produced by the microbiota in the intestines [9,41]. Nutritional components are known to impact on these pathways and are able to modify offspring development via these multiple trajectories providing links between microbiota, brain development and nutrition.

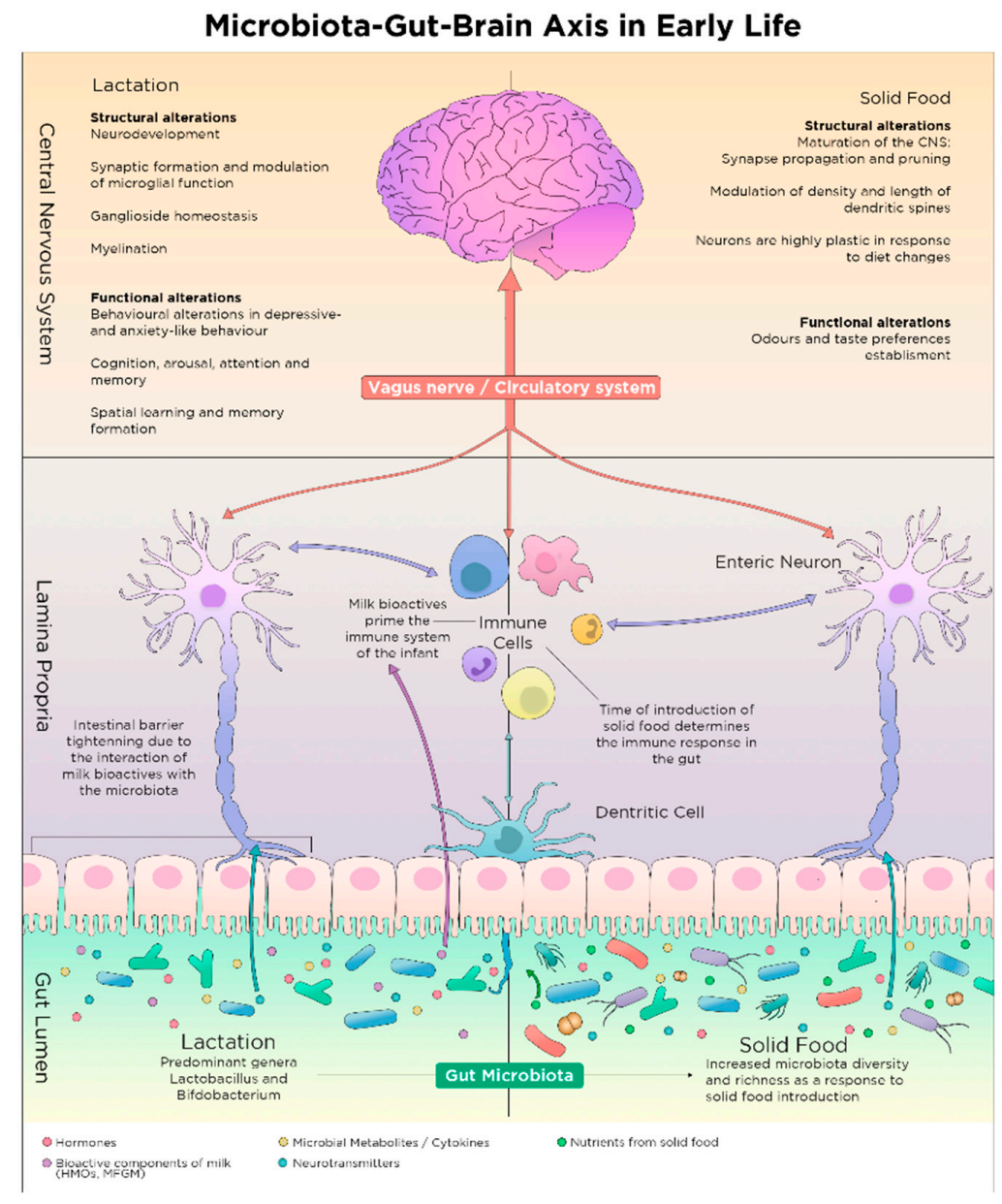

Figure 2. The effect of early life nutrition during lactation and solid food introduction on the gut microbiota development in the intestinal and the central nervous system; Microbes become more diverse and mature with solid food introduction compared to lactation. Microbes and metabolites in the gut lumen (hormones, neurotransmitters, microbial metabolites, cytokines and nutritional components from milk or solid food) affect the host physiology via the gut-brain axis; they modulate the epithelial barrier, the homeostasis in the lamina propria and the brain. Nutrients, metabolites and microbes in the gut lumen signal to dendritic cells and the enteric neurons which subsequently exchange signals with the immune the circulatory and the central nervous system. The vagus nerve, the immune and the enteric nervous system are all pathways of communication among the microbes, the gut and the brain. 


\subsection{Nutrient-Microbiota Interactions and Gut-Brain Axis}

The intestinal surface interacts with a plethora of microorganisms, as well as with food in the form of macro- and micronutrients that constitute substrate for host cells and microbes [43]. Nutrients and metabolites are sensed by the intestinal epithelial cells, initiating a hormonal cascade that eventually leads to nutrient absorption and transportation via the circulatory system to various tissues within the body [43]. Different pathways are activated in order to digest the various nutrients in the gut [44]. For instance, fatty acids in the gut are sensed by G-protein coupled receptors that mediate the production of incretinsgastrointestinal hormones-such as GLP1 that promotes insulin release from pancreatic cells [45]. While nutrients interact with microbiota, important secondary molecules are released to be later absorbed by the host. For example, prebiotic non-digestible dietary fibres are fermented by microbiota which release secondary metabolites that regulate important processes in the human body [46].

One category of highly potent by-products of fibre fermentation by the gut microbes are short-chain fatty acids (SCFAs), which include acetate, butyrate and propionate [47]. These metabolites are absorbed in the intestine and are able to modulate the CNS $[48,49]$ and the immune system $[50,51]$. Apart from their ability to cross the blood-brain barrier (BBB) and reach the brain, modulating structural and functional aspects of the CNS [47], SCFAs produced by commensals also affect the immune response via regulation of dendritic and T-cell function, as well as via inhibition of cytokine production [52] which affect brain development. It is becoming clear that the roots of the microbial and nutritional reciprocal relationship within the gut-brain axis and the balance between health and disease lie in the early life priming of these bodily systems supported by the initial nutrient-microbiota crosstalk [53].

\section{Early Nutrition-Microbiota Crosstalk in Sensitive Time Windows of Development}

Nutrition holds a central role in the early life maturation of many tissues within the body, with both short- and long-term effects on development of the infant, in an organ-, time- and intervention-dependent fashion, which is called nutritional programming [54]. Nutritional programming refers to the ability of highly potent molecules that are normally present in the diet or are de novo synthesized in our body to modulate and support early life development. There are multiple nutrients with epigenetic potential that are present in the diet or produced via microbial metabolism in the human gut [55]. B complex vitamins, SCFAs and polyphenols are among nutrients or microbial metabolites that are known to exert epigenetic effects on the host and affect fetal programming in sensitive time frames of development [55].

These sensitive time-periods are temporal windows of developmental opportunity that, if missed, alterations in growth and normal functions of body systems are irreversible $[56,57]$. These periods include pre-conception, pregnancy, peri- and early postnatal life that are characterized by rapid changes in maturation of neuronal, immune, endocrinal and metabolic processes [58,59]. The quality and quantity of food received during these sensitive periods are crucial indicators of weight gain and metabolic regulation [54,60], as well as CNS development, microbiota composition and immune system priming of the individual across the lifespan $[42,56,61-63]$.

\subsection{Nutritional and Microbial Regulation in Pre-Conception}

Parental nutrition and health status prior to conception are crucial for the appropriate structural development of the CNS of the offspring (see Figure 1). Certain micronutrients with epigenetic potential, such as folate, are recommended to women who plan to get pregnant or are already in early stage of pregnancy in order to prevent infant neural tube defect and other congenital malformations [64]. However, vitamin kinetics and drugmicrobiota-nutrient interactions should be considered while receiving supplementation. For instance, certain bacteria in the gut are able to produce de novo folate as a secondary molecule of their metabolism [65]. Furthermore, exposure to oral contraceptives or anti- 
epileptic drugs might decrease the availability of folate in the body [66,67], thus risking congenital malformations in the case of pregnancy.

Increasing research suggests that environmental influence on parental health can modulate functional aspects of infant development, such as offspring's behaviour later in life $[68,69]$. Recent preclinical data revealed that paternal immune activation due to infection modulates offspring behaviour via epigenetic regulation of the paternal reproductive cells, with persistent inheritable potential for at least two generations [70]. Modulation of the maternal immune system by environmental factors, before and during pregnancy, is able to induce persistent alterations in offspring health from early life throughout adulthood [71,72].

Expanding data point to the existence of critical temporal windows before conception, regarding parental nutrition and microbial metabolites shaping the immune system of the offspring [63,73-75]. In rodents, reduced parental exposure to bacteria prior to conception could lead to allergic disease in the offspring via epigenetic regulation of immunomodulatory genes, that passes to the next generation [72]. Nutritional-microbial crosstalk is able to exert inheritable changes in the germline and holds a central role in fetal programming of central nervous and immune systems.

\subsection{Nutrition-Microbial Input on Neurodevelopment in Pregnancy}

The brain is subjected to multiple structural and functional, time-specific changes during gestation such as axonal growth [76], synapse formation and dendritic and axonal arborization [77]. After neuronal differentiation, synaptic connections among neurons continue to develop during gestation [78]. During the early phase of the cascade of those time-dependent and strictly controlled events, disruptions can determine the fate of brain function later in life [78]. Therefore, this period is crucial for structural (brain connectivity) and functional (cognitive development and behaviour) outcomes in the brain [79]. During pregnancy, maternal factors (diet, lifestyle, mental health, antibiotic use) as well as environmental factors (infection, air pollution, tobacco or radiation exposure) impact the health of the pregnant mother $[80,81]$ and affect fetal development via transplacental signals, including signals from maternal intestinal microbes and nutrients [53] (see Figure 1).

\subsubsection{Maternal Nutrition and Fetal Neurodevelopment}

Maternal nutrition during pregnancy can modulate some of the multiple structural and functional changes that are happening in the offspring brain perinatally [78]. In fact, nutrient intake influences micro- and macro-structural aspects of the brain during various time points of brain development $[82,83]$ via regulation of neurotransmitter pathways, synaptic transmission and signal-transduction pathways $[61,84]$. Such nutrients are the $\omega-3$ polyunsaturated fatty acids which have a known effect on brain plasticity, cognition and brain health via regulation of hippocampal BDNF in rodents [82]. In humans, $\omega-3$ fatty acid consumption in early life is associated with improved cognition, while decreased levels of $\omega-3$ fatty acids have been found in the brain of individuals with mental health and neurodegenerative conditions [82,83].

Nutrient deficiencies in the mother during pregnancy may result in abnormal neurodevelopment of the fetus, in humans, which leads to related adversities in the adult offspring [85,86]. For instance, molecules affecting one-carbon metabolism like folate, choline and betaine, have known epigenetic potential in nervous system development of the offspring [87]. All of these molecules are present in green leafy vegetables, as well as in beets, wheat and seafood [88], while folate can be synthesized as a secondary metabolic product of certain bacteria in the gut [65]. Optimal nutrition is required to support brain macro- and micronutrient requirements for its maximum developmental potential [83].

\subsubsection{Maternal Nutrition and Offspring Gut Microbiota Development}

Dietary habits during the period of gestation can shape the maternal intestinal microbiota $[81,89]$ which result in altered microbial metabolites in the maternal intestines. For 
instance, dietary fibres in the maternal intestines are fermented by maternal microbes with the subsequent release of microbial by-products known as SCFAs. The SCFAs are able to pass from the gut lumen to the circulation and travel to the fetus via the placenta [90]. SCFA and other microbial metabolites from the maternal intestines, are able to imprint in-utero development with possible health outcomes on the offspring across lifespan $[53,90]$.

Maternal weight and obesity have been associated with alteration in composition of the gut microbiota, with obese individuals displaying altered microbial profiles compared to normo-weight individuals [91]. Microbial signatures of overweight and obesity have been found to pass from mothers to infants, with infants from obese mothers obtaining distinct microbiota profile compared to infants from normo-weight mothers [92,93]. Moreover, stool microbiota analysis has shown decreased abundance of the Bifidobacterium group in babies of overweight mothers compared to babies born to normo-weight mothers [92] emphasizing the possible role of Bifidobacterium on weight development and weight control of the infant.

In a cohort of Hispanic mother-infant pairs, low levels of Bacteroides have been found in neonatal meconium samples from infants with mothers exposed to a diet with increased fat content ( $>40 \%$ of daily intake) during pregnancy, with those low levels of Bacteroides persisted until 6 weeks of age [81]. The Bacteroides genus, part of the commensal bacteria in the gut, is present in low amounts in the infant gut right after birth and it becomes gradually more abundant after solid food introduction [94]. Low counts of Bacteroides in adulthood have been previously associated with obesity and altered metabolic capability of the host [94].

In preclinical studies, maternal dietary manipulations during pregnancy can modify the offspring microbiota composition [95]. For instance, in rodents, microbial diversity and composition of pups originating from dams exposed to a high-fat diet (HFD) (60\% of daily intake) during pregnancy was altered, with reduced abundance of Lactobacillus reuteri, Bifidobacterium pseudolongum and Bacteroides uniformis present in the faeces of pups originating from dams exposed to HFD compared with pups originating from dams exposed to normal chow diet (13.4\% of daily intake) [96]. Additionally, microbiota composition changes in the offspring as a result of maternal HFD during pregnancy were accompanied by impairments in social behaviour of the pups tested by the reciprocal social interaction and the three chambers social interaction tests [96]. Moreover, maternal high-fibre diet $(21 \% \mathrm{wt} / \mathrm{wt}$, 1:1 ratio of oligofructose and inulin) in rats during pregnancy and lactation modified the gut microbiota of the dam and the offspring [97], probably via a combined effect of vertical transmission of maternal microbiota during birth, and breast milk microbiota in the suckling pups.

Apart from maternal nutrition during pregnancy, there are other factors modulating the offspring's intestinal microbiota composition in early life such as mode of delivery, type and duration of feeding (see Figure 1) which are discussed in separate sections below. Maternal antibiotic exposure perinatally, as well as infant antibiotic exposure postnatally are strong modifiers of offspring microbiota composition and have been recently discussed elsewhere [6].

\subsubsection{Maternal Microbial Signatures in Pregnancy Prime Fetal CNS}

The composition of the maternal gut microbiota varies dramatically in response to hormonal, immunological and metabolic changes that take place during pregnancy [98]. It is known that there are tight molecular and cellular interactions between mother and fetus via the placenta [99]. The maternal microbiota produces compounds that are transported to the fetus via transplacental pathways leaving metabolic signatures to the developing fetus [98] and these prenatal microbial signatures can tip the balance between health and disease $[53,100]$.

For the past decade, scientists examined controversial data regarding the possibility of a non-sterile environment during the course of gestation [75,101,102]. Recently, sparse but viable microbiota have been identified in the fetal gut at mid-gestation in humans [75]. 
However, this clinical study has been recently heavily criticised by other researcher of the field $[103,104]$ who claim that contamination of the samples during analysis is the most probable explanation for the bacteria found in the fetal gut. Researchers who analysed meconium (the first faecal sample of the new-born) found low amounts of viable bacteria present but confirmed that the main bacterial colonization of the gut happens at the time of birth [105]. Even though it is difficult to assess the 'in-utero sterility hypothesis' due to possibility of external contamination of samples, it is believed that microbes and their metabolites in the maternal intestines influence in-utero CNS development and function [106].

The assembly of fetal neuronal circuits can be perturbed in response to maternal and environmental microbial disruptions during pregnancy. Recent data suggest that depletion and partial reconstitution of the maternal microbiota during pregnancy modulate fetal thalamocortical neurodevelopment in rodents -via transplacental metabolic signals-which is linked to sensorimotor behaviour and pain perception postnatally [106]. Additionally, microbial signatures of maternal stress during pregnancy are able to pass to the next generation, modulate hippocampal development and gut function in adult male offspring in mice [107]. Epidemiological studies focused on maternal infection has shown that maternal immune activation (MIA) perinatally is associated with impaired fetal brain development and higher risk of acquiring psychiatric disorders in adulthood [108,109]. Therefore, changes or perturbations of the maternal microbiota during gestation primes fetal neurodevelopment during this critical period and might determine cognitive, sensory and behavioural function of the offspring throughout the lifespan. Data present in the current review are referred to term-born infants (unless otherwise specified), as the effect of premature birth on the microbiota [110] and the brain development have been discussed elsewhere [111].

\subsection{Mode of Birth and Microbiota}

\subsubsection{Vaginal Delivery and Vertical Transmission of Microbiota}

Today it is understood that the initial microbiota inoculation begins at birth while the fetus passes through the birth canal and is exposed to maternal vaginal and faecal microbiota [1]. This constitutes the first moment leading to extensive microbiota colonization of the neonate; multiple studies have reported the impact of delivery mode on the neonate's first microbial exposure $[1,101,112]$. Dominguez-Bello and colleagues demonstrated that there is vertical transmission of the maternal microbiota to the new-born in vaginal delivery, meaning that the neonatal microbiota resemble the maternal vaginal and faecal microbiota [1]. These vertically transmitted microorganisms have the potential to affect the development of intestinal microbiota in the offspring during early life and may relate to host health later in life [113].

\subsubsection{Caesarean Section and the Missing Microbes}

During Caesarean-section (C-section) the infant is not exposed to the maternal vaginal and faecal microbiota and the vertical transmission is disrupted [1]. Interestingly, it is understood that the intestine of $\mathrm{C}$-section delivered new-borns is predominantly colonized by bacteria present on the skin and in the environment $[1,112]$. In contrast with vaginal delivery, the microbiota of C-section babies was found to display decreased diversity and richness [114], with C-section being associated with significantly lower levels of bacterial genera essential to brain development such as Bifidobacterium, Lactobacillus and Bacteroides [112,115], and higher levels of Staphylococcus [1].

However, emergency C-section impacts the microbiota differently compared with elective C-section, due to the fact that the neonate is partly exposed to the birth canal in the early stages of labour [116-118]. In the case of emergency C-section, the newborn microbiota resembles more closely the composition of vaginally-delivered babies [119]. Interestingly, elective and emergency $\mathrm{C}$-section have been also found to alter microbial diversity and richness in breast milk $[120,121]$. Even though depletion of specific microbiota 
in breast milk could be partly explained by administration of antibiotics to the mother during C-section procedures, it has been recently proven that $\mathrm{C}$-section is an independent modifier of breast milk microbiota [121] indicating this can also contribute to the differences seen between babies born via different modes.

Mode of delivery is a strong modifier of the relationship between maternal perinatal nutrition and postnatal infant microbiota composition development [81]. In a clinical study pre-pregnancy maternal weight impacts infants' microbiota composition in babies born vaginally to obese mothers, but not via C-section [93]. The disruption of vertical transmission in this case might be beneficial for the microbiota composition development of the offspring and prevent the 'obese' microbial signatures that could have passed with vertical transmission and could relate to offspring health later in life.

Although mode of delivery has a widely known impact on the new-born microbiota, its exact influence on microbiota shaping throughout the lifespan is still rather controversial due to confounding factors (i.e., pre-existing conditions such as pre-eclampsia, emergency or elective C-section and antibiotic use during surgery) [119]. Even though the impact of being born via C-section leaves microbial signatures up to four years of age in a recent human cohort [118], other studies claim that the microbial composition of C-section individuals recovers with of time, displaying a transient effect [112].

Ways of modulating gut microbiota such as faecal microbiota transplantation (FMT) in both clinical and preclinical context, are being studied. It is evident that microbiota interventions like FMT could reinstate gut microbiota composition of individuals with clinical or subclinical intestinal conditions such as diarrhoea, IBD and intestinal infections [122]. Most studies on early life FMT are focused on the treatment of symptoms of IBD or recurrent infections of C. Difficile [123]. The concept of FMT in C-section individuals is novel, in order to reinstate the gut microbiota of those individuals to resemble more the microbes of vaginally-delivered infants. Indeed, such an approach was taken in a recent small clinical study where seven C-section delivered new-borns received FMT shortly after birth from their mothers' faecal microbes [124]. The FMT was able to restore the microbial differences between C-section and vaginally-born infants up to 3 months of age [124]. Future studies are needed to explore the feasibility and safety of such approaches in the future.

Most developmental studies investigating the mode of delivery focus on bacteria but, recently scientists are shifting their interest on the effect of birth mode to the gut virome (the assemblage of viruses present in the intestine) and phageome (the bacteriophage community present in the intestine) $[125,126]$ which may also contribute to the future health of the offspring.

\subsubsection{C-Section-Related Risks and Adversities}

Early life disruption of microbiota by C-section has been associated with some wellknown disorders in childhood and adulthood. In clinical studies, C-section has been correlated with immune disorders including asthma and allergies [127-129], along with obesity [130] and type 2 diabetes [114,131]. In human epidemiological studies there have been links between C-section and school performance $[132,133]$ but this has not been reproduced in other datasets [134]. Moreover, a small association between planned Csection and visual-spatial cognitive delay in childhood has been reported [135]. In preclinical studies, C-section is linked to neurodevelopmental structural changes that are accompanied by early life behavioural alterations on infant vocalization during maternal separation [136,137] as well as anxiety-like behaviour throughout lifespan [138].

It could be hypothesized that behavioural effects due to differential microbial colonization as a result of C-section, are possibly extended to later stages of life, affecting multiple aspects of social behaviour. However, more studies are needed to investigate the long-term microbiota changes and behavioural effects of delivery mode, with shifting focus to the missing microbes in C-section delivered individuals. Targeting the behavioural effects with probiotic intervention strategies to potentially rescue behavioural deficits is a rather promising avenue for those individuals. 


\subsection{Shaping of Microbiota Composition and Neurodevelopment via Postnatal Early Life Nutrition}

The brain is highly metabolically active in early life and its energy expenditure accounts for half of the total daily resting energy metabolism [61]. At full term birth, the brain weighs around $350 \mathrm{~g}$, representing only around $10 \%$ of infant's body weight, while at one year of age the brain weight reaches $925 \mathrm{~g}$ which accounts for $70 \%$ of the adult brain weight ( 1300-1400 g) [78]. The high brain-weight to body-weight ratio, anatomical, structural and functional brain changes, as well as the demanding metabolic rate of the $\mathrm{CNS}$, are indications that CNS development in critical time windows is sensitive to energy and nutrient availability, which is believed to define the fate of development, physiology and mental health later in life [61].

\subsubsection{The Microbiota Expansion and the First Food after Birth}

The new-born gut is mainly colonized by various species of Bifidobacterium, that are also highly abundant among the commensals in the maternal breast milk. The offspring gut microbiota modulates multiple levels of development, almost immediately following birth. For instance, certain bacteria have been shown to stimulate gene expression of tight junctions in mice, boosting the closure of the gaps between epithelial cells and promoting gut barrier maturation postnatally, that is known to be immature in the early steps of life [139]. In the intestine, Bifidobacteria have been found to boost gut barrier function, and improve intestinal disease outcome by decreasing the intestinal permeability in rodents [140]. In preclinical models, Bifidobacterium can alter structural characteristics of the CNS and modify neurodevelopment in early postnatal life by promoting synaptic formation and microglial function postnatally [141], while in later stages of development these bacteria have been found to rescue behavioural deficits such as anxiety- and depressive-like behaviour [142,143]. Collectively, all these findings highlight the importance of Bifidobacterium in regulating multiple aspects of development following microbial colonization at birth.

Soon after birth, microbiota in the infant gut is nurtured and shaped by the dietary and bioactive components of milk that are discussed below (see Section Bioactive Components of Breast Milk and Figure 2). Breastfeeding, breast milk from donors and infant formula are the three options currently available for early life nutrition [144]. The nutritious and bioactive interchange of the first food with microbiota in the infant gut inextricably and constantly modulate the microbiota composition of the infant which might relate to several aspects of infant development [145]. Early life nutrition determines the fate of microbial colonization, as well as the development of the GI tract, the immune and the central nervous system of the infant [146].

\subsubsection{Breastfeeding and Composition of Breast Milk Breastfeeding}

Breastfeeding is considered the gold standard for infant nutrition as it is tailored to provide various micro- and macronutrients for the demanding development of the new-born in a time-dependent manner $[145,147]$. Beyond its nutritional benefits, breastfeeding exerts other protective benefits for the developing child; it is known to enhance neurodevelopment and to boost the immune system in early life, but is also associated with decreased risk of childhood obesity and type 2 diabetes $[146,148]$. Furthermore, exclusive breastfeeding is highly recommended for the first 6-months of life, it is convenient and inexpensive, and it strengthens the bonding between mother and baby $[149,150]$.

\section{Maternal Characteristics, Breast Milk and Child Development}

Breast milk composition is highly affected by maternal characteristics such as mental health [151], nutrition and lifestyle choices [152,153], protein intake, the return of menstruation, and nursing frequency [154]. Maintaining a healthy maternal body and mind during lactation influences the quality of breast milk which in turn is crucial for infant development [155]. 
The perinatal period is a time that women are highly sensitive to psychosocial and psychological stress as well as anxiety, which may induce perinatal depression to susceptible mothers [156]. Maternal exposure to stress and depression perinatally can lead to changes in mood, inadequate food consumption and lifestyle choices (lack of physical activity, alcohol consumption, smoking and substance abuse) and might affect lactation and the quality and composition of the breast milk [80,151].

Changes in breast milk composition due to maternal psychopathologies could eventually impact the neurodevelopmental outcome of the infant [151]. For example, in humans, postpartum depression has been found to modulate the concentration of polyunsaturated fatty acids (PUFAs) in breast milk, which in turn, are associated with increased risk of mental health conditions of the offspring [157,158]. Moreover, maternal mental health conditions (such as perinatal stress and postpartum depression) were assessed in an African population by Perceived Stress Scale questionnaires on days 3, 9, and 14 postpartum. Breast milk and saliva were collected on the same days as the questionnaires. Positive correlations were found in this study, between maternal stress and breast milk interleukin- 8 at day 3, and with macrophage inflammatory protein-1-alpha (MIP-1 $\alpha$ ) at day 14 postpartum [159]. Cytokines in breast milk are able prime the CNS, immune system [160] and might modulate the microbiota composition of the new-born during critical temporal windows of development.

During the demanding period of lactation, the maternal energy requirements are increased; even though this depends on the stage of lactation [150], the general recommendations for the lactating mother (normo-weight) during exclusive breastfeeding, suggest consumption of extra $650 \mathrm{kcal} /$ day [153]. However, if those extra calories are not consumed, the energy drawn from internal maternal stores to maintain lactation [150]. Breast milk composition is affected by maternal energy consumption and food choices during lactation [152,153]. However, the ability to produce milk is independent of certain maternal factors such as maternal weight, BMI, body composition and gestational weight [161]. Nowadays, various popular diets like vegetarian and vegan, might lack certain vitamins and calcium and therefore lactating women with these dietary choices might require supplementation during the breastfeeding period [150,162].

Non-maternal characteristics but situations linked to pregnancy such as premature birth (delivery before the beginning of the 37th week of gestation) cause changes in human milk composition. Breast milk of mothers with premature delivery contained significantly higher amounts of protein and immunological components compared to milk from fullterm mothers [163]. Interestingly, protein content of the human milk was associated with the maternal BMI but not the maternal diet [154]. The composition of the human milk is also affected by the breastfeeding frequency, as the higher the nursing frequency the higher levels of lactose and lower levels of fat and protein are found in human milk [147,154].

Human milk composition is dynamic, varies within a feeding, diurnally, over the different stages of lactation, and between mothers [151]. Breast milk composition changes dramatically over the first month of life in order to match the new-born's needs in macronutrients and immunity, but only subtle changes are identified in breast milk composition after the first month of lactation [147]. So far, three separate stages of lactation have been determined according to the composition of breast milk, which are summarized in Table 1 and Figure 3. 
Table 1. Main components of human milk on the three stages of lactation and the effect on infant health. The cessation of breastfeeding is specific to each mother-infant dyad; it is decided according to the needs of the infant and upon the choice of the mother.

\begin{tabular}{|c|c|c|c|c|}
\hline Stages of Lactation & Duration & Components & Effect on & References \\
\hline Stage 1: Colostrum & 1-5 days postnatally & $\begin{array}{c}\text { Very rich in immunoglobulins, lactoferrin, } \\
\text { leukocytes, growth factors, vitamins A } \\
\text { and E, proteins and fat low quantities } \\
\text { of lactose }\end{array}$ & $\begin{array}{l}\text { Immune system } \\
\text { development }\end{array}$ & {$[147,151]$} \\
\hline $\begin{array}{l}\text { Stage 2: Transitional } \\
\text { milk }\end{array}$ & $1-2$ weeks postnatally & $\begin{array}{l}\text { Richer in lactose and fat compared to } \\
\text { colostrum, richer in proteins and fat } \\
\text { compared to mature milk }\end{array}$ & $\begin{array}{l}\text { Nutritional } \\
\text { needs of the } \\
\text { baby }\end{array}$ & {$[147,151]$} \\
\hline \multirow{2}{*}{ Stage 3: Mature milk } & \multirow{2}{*}{$\begin{array}{l}\text { 1st month-end of } \\
\text { lactation }\end{array}$} & $\begin{array}{l}\text { Richer in lactose and water compared to } \\
\text { colostrum and transitional milk }\end{array}$ & \multirow{2}{*}{$\begin{array}{l}\text { Nutritional } \\
\text { needs of the } \\
\text { baby }\end{array}$} & [151] \\
\hline & & $\begin{array}{l}\text { Richer in vitamins B1 and B6 compared to } \\
\text { colostrum and transitional milk }\end{array}$ & & {$[147,151]$} \\
\hline
\end{tabular}

\section{Main nutritional components across different stages of lactation}

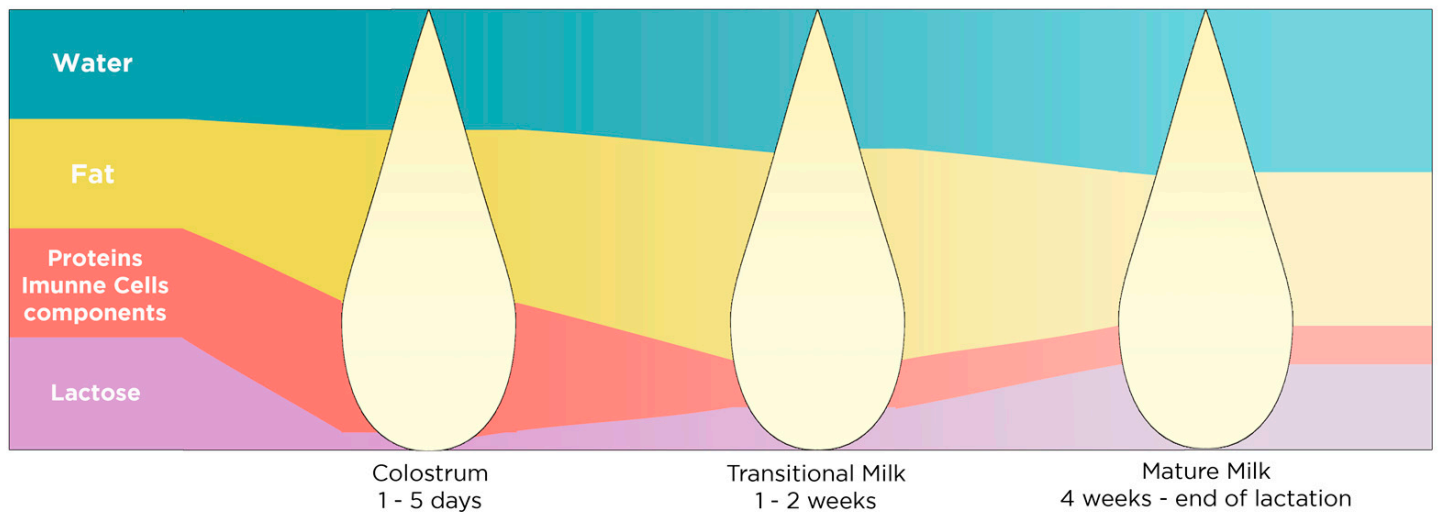

Figure 3. Main nutritional and bioactive components in the different stages of lactation. The quantity of the main nutritional components stays consistent in mature milk, after the 1st month of lactation until the cessation of breastfeeding.

\section{Macro- and Micronutrient Composition of Breast Milk}

Breast milk is composed of a distinct combination of constituents that leads to specific metabolic and physiological responses in children, regulating intestinal function, immunity and brain development [60]. The components of human milk are derived from three primary sources: maternal diet, maternal macro- and micro-nutrient stores and the production of nutrients in the lactocyte (milk-producing cell located at the mammary gland) [147].

Macronutrient composition of breast milk varies within mothers and across lactation and it highly depends on maternal diet [152]. However, macronutrient composition differs according to the stage of lactation with early milk being richer in protein and fat compared to term milk [147]. Micronutrients in human milk such as vitamins and minerals depend highly on maternal diet and internal stores [152]. The most abundant macro- and micronutrients in breast milk can be found in Table 2 .

\section{Bioactive Components of Breast Milk}

Multiple bioactive milk components have been found to modulate the immune system via gut microbiota $[63,164]$, enhance CNS development and promote gut health in early life $[151,165]$. These promiscuous molecules are produced in the mammary gland, or by cells present in the human milk like immune cells, while some are transported into the mammary gland via circulation. Three of the most abundant bioactive components in 
human breast milk including milk fat globule membranes (MFGM), human milk oligosaccharides (HMOs) and breast milk microbiota are summarized in Table 3. Some bioactive components of breast milk, like the MFGM, may act as macronutrients too, providing the infant with energy or acting as building blocks for growth of various tissues.

Table 2. Macro and micronutrients present in human milk, their effect on infant health and their expression in different stages of lactation.

\begin{tabular}{|c|c|c|c|c|c|c|}
\hline $\begin{array}{l}\text { Category of } \\
\text { Molecule }\end{array}$ & $\begin{array}{l}\text { Breastmilk } \\
\text { Component }\end{array}$ & $\begin{array}{l}\text { Subcategory of } \\
\text { Molecule }\end{array}$ & Effect on & References & Population & $\begin{array}{l}\text { Highly Present in } \\
\text { which Stage of } \\
\text { Lactation }\end{array}$ \\
\hline \multirow{9}{*}{ Macronutrients } & Casein & \multirow{6}{*}{ Proteins } & \multirow{6}{*}{$\begin{array}{l}\text { Immune system } \\
\text { development, general } \\
\text { growth and } \\
\text { development }\end{array}$} & [166] & $\begin{array}{l}\text { Humans: } \\
\text { multiple }\end{array}$ & \multirow{6}{*}{$\begin{array}{l}\text { More abundant in } \\
\text { colostrum compared } \\
\text { to mature milk }\end{array}$} \\
\hline & $\alpha$-Lactalbumin & & & [167] & $\begin{array}{l}\text { Humans: } \\
\text { multiple }\end{array}$ & \\
\hline & Lactoferrin & & & [168] & $\begin{array}{l}\text { Humans: } \\
\text { multiple }\end{array}$ & \\
\hline & Immunoglobulins & & & [169] & $\begin{array}{l}\text { In vitro, mice \& } \\
\text { humans }\end{array}$ & \\
\hline & Lysozyme & & & [147] & $\begin{array}{l}\text { Humans: } \\
\text { multiple }\end{array}$ & \\
\hline & Serum albumin & & & [166] & $\begin{array}{l}\text { Humans: } \\
\text { multiple }\end{array}$ & \\
\hline & $\begin{array}{l}\text { Palmitic and } \\
\text { oleic acid }\end{array}$ & \multirow{2}{*}{$\begin{array}{l}\text { Heterogenous } \\
\text { mixture of } \\
\text { proteins, lipids, } \\
\text { fatty acids and } \\
\text { cholesterol }\end{array}$} & $\begin{array}{c}\text { General growth and } \\
\text { development }\end{array}$ & [170] & $\begin{array}{l}\text { Humans: } \\
\text { multiple }\end{array}$ & \multirow{2}{*}{$\begin{array}{l}\text { Richer in colostrum } \\
\text { compared to mature } \\
\text { milk and richer in } \\
\text { evening compared to } \\
\text { morning feedings }\end{array}$} \\
\hline & $\begin{array}{l}\text { Milk fat globule } \\
\text { membranes: } \\
\text { MFGM }\end{array}$ & & $\begin{array}{c}\text { Cognition, } \\
\text { neurodevelopment, } \\
\text { boost immune system } \\
\text { against infections }\end{array}$ & {$[165,171,172]$} & $\begin{array}{l}\text { In vitro, mice } \\
\text { and humans }\end{array}$ & \\
\hline & Lactose & Carbohydrates & $\begin{array}{l}\text { Growth and } \\
\text { development }\end{array}$ & [147] & $\begin{array}{l}\text { Humans: } \\
\text { multiple }\end{array}$ & $\begin{array}{l}\text { More abundant in } \\
\text { mature milk and } \\
\text { when milk is } \\
\text { expressed more } \\
\text { frequently }\end{array}$ \\
\hline \multirow{3}{*}{ Micronutrient } & $\begin{array}{l}\text { Vitamins A } \\
\text { and E }\end{array}$ & Vitamins & $\begin{array}{l}\text { Growth and } \\
\text { development }\end{array}$ & {$[147,151]$} & $\begin{array}{l}\text { Humans: } \\
\text { multiple, mice } \\
\text { and rats }\end{array}$ & $\begin{array}{l}\text { Higher in colostrum } \\
\text { compared to mature } \\
\text { milk }\end{array}$ \\
\hline & $\begin{array}{l}\text { B complex } \\
\text { vitamins }\end{array}$ & Micronutrients & $\begin{array}{l}\text { Epigenetic potential, } \\
\text { neurotransmitter } \\
\text { synthesis, } \\
\text { neurodevelopment, } \\
\text { protection from } \\
\text { neural tube defect }\end{array}$ & [15] & $\begin{array}{l}\text { In vitro, mice } \\
\text { and humans }\end{array}$ & $\begin{array}{l}\text { B1 and B6 higher in } \\
\text { mature milk } \\
\text { compared to } \\
\text { colostrum }\end{array}$ \\
\hline & $\begin{array}{l}\text { Iron, copper } \\
\text { and zinc }\end{array}$ & Metals & $\begin{array}{l}\text { Neurodevelopment, } \\
\text { haematopoiesis }\end{array}$ & {$[147,151]$} & $\begin{array}{l}\text { In vitro, mice } \\
\text { and humans }\end{array}$ & $\begin{array}{l}\text { Higher in colostrum } \\
\text { compared to mature } \\
\text { milk }\end{array}$ \\
\hline
\end{tabular}


Table 3. Bioactive components of human milk and their effect on infant health.

\begin{tabular}{|c|c|c|c|c|c|}
\hline Breastmilk Component & $\begin{array}{l}\text { Subcategory of } \\
\text { Molecule }\end{array}$ & Effect on & References & Population & Stage of Lactation \\
\hline \multirow{3}{*}{$\begin{array}{l}\text { Epidermal growth } \\
\text { factor (EGF) }\end{array}$} & \multirow{6}{*}{ Growth factors } & $\begin{array}{l}\text { Intestinal maturation, immune system } \\
\text { imprinting during weaning }\end{array}$ & [164] & Mice & \multirow{3}{*}{$\begin{array}{l}\text { Present as long as } \\
\text { the lactation lasts }\end{array}$} \\
\hline & & $\begin{array}{l}\text { Enterocyte stimulation for nutrient } \\
\text { absorption }\end{array}$ & [173] & Pigs, human & \\
\hline & & $\begin{array}{l}\text { Tight junction and cell death regulation } \\
\text { in response to gut inflammation }\end{array}$ & [174] & Rats & \\
\hline \multirow{2}{*}{$\begin{array}{l}\text { Brain-derived } \\
\text { neurotrophic factor } \\
\text { (BDNF) }\end{array}$} & & $\begin{array}{l}\text { Normal growth, development and } \\
\text { function of neurons in the CNS* and } \\
\text { PNS* }\end{array}$ & [175] & Rats & \multirow{3}{*}{$\begin{array}{l}\text { Present in breast } \\
\text { milk up to } 90 \text { days } \\
\text { postnatally }\end{array}$} \\
\hline & & $\begin{array}{l}\text { Increase intestinal motility by } \\
\text { stimulation of the ENS* }\end{array}$ & [176] & $\begin{array}{l}\text { In vitro and rats } \\
(e x \text { vivo })\end{array}$ & \\
\hline $\begin{array}{l}\text { Glial-derived } \\
\text { neurotrophic factor } \\
\text { (GDNF) }\end{array}$ & & $\begin{array}{l}\text { Normal growth, development and } \\
\text { function of glial cells in the CNS* and } \\
\text { PNS*, supports neuronal health and } \\
\text { development }\end{array}$ & [175] & Mice and rats & \\
\hline Erythropoietin (EPO) & \multirow{7}{*}{ Hormones } & $\begin{array}{l}\text { Protective effect on intestinal tight } \\
\text { junction, prevent anaemia and reduces } \\
\text { the risk of necrotizing enterocolitis }\end{array}$ & [177] & In vitro & \\
\hline \multirow[t]{2}{*}{ Adiponectin } & & $\begin{array}{l}\text { Regulates metabolism and suppresses } \\
\text { inflammation }\end{array}$ & {$[178,179]$} & $\begin{array}{l}\text { Humans: Hispanic, } \\
\text { mice and humans, } \\
\text { humans: Hispanic }\end{array}$ & \\
\hline & & Regulates body weight later in life & {$[178,179]$} & $\begin{array}{l}\text { Mice and humans, } \\
\text { humans: Hispanic }\end{array}$ & \\
\hline Ghrelin and leptin & & $\begin{array}{c}\text { Control appetite, body composition and } \\
\text { metabolism }\end{array}$ & {$[180,181]$} & $\begin{array}{l}\text { Humans: multiple, } \\
\text { Humans: Caucasians, } \\
\text { humans: multiple }\end{array}$ & \\
\hline Prolactin & & Stimulating milk production & [151] & $\begin{array}{l}\text { Humans: multiple, } \\
\text { mice and rats }\end{array}$ & \\
\hline \multirow{2}{*}{ Oxytocin } & & $\begin{array}{l}\text { Production stimulated in } \mathrm{PVN}^{*} \text { by skin } \\
\text { to skin contact with the mother }\end{array}$ & {$[151,182]$} & Humans: multiple & \multirow{2}{*}{$\begin{array}{l}\text { Low levels in breast } \\
\text { milk }\end{array}$} \\
\hline & & Sociability & [183] & $\begin{array}{l}\text { Mice and Humans: } \\
\text { multiple }\end{array}$ & \\
\hline Breast milk microbiota & Microbiota & $\begin{array}{l}\text { Modulate the gut-brain axis, boost gut } \\
\text { barrier function, improve the } \\
\text { development of intestinal diseases, are } \\
\text { able to rescue behavioural deficits, as } \\
\text { well as anxiety-like and depressive-like } \\
\text { behaviour, in preclinical models, } \\
\text { regulate cytokine and tryptophan levels } \\
\text { in mice, shape neurodevelopment, } \\
\text { promote synaptic formation and } \\
\text { microglial action }\end{array}$ & [141-143] & $\begin{array}{l}\text { Rats, mice, humans: } \\
\text { multiple, mice }\end{array}$ & $\begin{array}{l}\text { Through the course } \\
\text { of lactation }\end{array}$ \\
\hline \multirow{4}{*}{$\begin{array}{c}\text { Human-milk } \\
\text { oligosaccharides } \\
\text { (HMOs) } \\
\text { (lacto-N-tetraoze, } \\
\text { 2-Fucusyllactose) }\end{array}$} & \multirow{4}{*}{$\begin{array}{c}\text { Carbohydrates + } \\
\text { prebiotics } \\
\text { (concentration varies } \\
\text { depending on stage } \\
\text { of lactation) }\end{array}$} & Modulate the microbiota-gut-brain axis & {$[151,184-187]$} & $\begin{array}{l}\text { In vitro, mice, rats and } \\
\text { humans: multiple }\end{array}$ & \multirow{4}{*}{$\begin{array}{l}\text { Through the course } \\
\text { of lactation }\end{array}$} \\
\hline & & $\begin{array}{l}\text { Protect from infection in the gut by } \\
\text { reducing colonization of pathogens and } \\
\text { promoting the viability and diversity of } \\
\text { commensals }\end{array}$ & [184] & $\begin{array}{l}\text { Mice, rats and humans: } \\
\text { multiple }\end{array}$ & \\
\hline & & Improve cognitive development & [187] & Humans: Hispanic & \\
\hline & & $\begin{array}{l}\text { Inducing maturity of epithelial cells and } \\
\text { improve gut barrier function }\end{array}$ & {$[151,184-187]$} & $\begin{array}{l}\text { In vitro, mice, rats and } \\
\text { humans: multiple }\end{array}$ & \\
\hline Macrophages & \multirow{2}{*}{ Cells } & $\begin{array}{l}\text { Protection against infection, T-cell } \\
\text { activation }\end{array}$ & {$[169]$} & $\begin{array}{l}\text { Humans: Indo-Aryan } \\
\text { and In vitro, mice }\end{array}$ & \multirow{2}{*}{$\begin{array}{l}\text { More abundant in } \\
\text { colostrum than } \\
\text { mature milk }\end{array}$} \\
\hline Stem cells & & Regeneration and repair & {$[188]$} & $\begin{array}{l}\text { Humans: Caucasian, } \\
\text { Indo-Aryan }\end{array}$ & \\
\hline
\end{tabular}

CNS*: central nervous system, PNS*: peripheral nervous system, ENS*: enteric nervous system, PVN*: paraventricular nucleus.

\section{Milk Fat Globule Membrane}

Milk fat globules (MFG) are lipid droplets surrounded by a phospholipid tri-layer and are secreted locally by the mammary lactocytes [165,189]. The tri-layer surrounding the MFG, called milk fat globule membrane (MFGM), has a unique complex structure consisting of phospholipids, glycolipids, carbohydrates and proteins, as well as associated transmembrane growth factors on its surface, all of which have bioactive proper- 
ties [165,189]. MFGM and its associated proteins are present in higher concentrations in the colostrum compared to mature milk [190]. MFGM composition varies across different stages of lactation, and it is influenced by maternal factors such as body composition, diet, gestation period, infant sex, and environmental factors such as infections [189].

The lipid to protein weight ratio in MFGM is approximately 1:1, highlighting the protein presence at the MFGM [172]. Among many MFGM-associated proteins that have been identified in human milk, lactadherin, butyrophilin and mucins stand out as they are able to resist gastric digestion, and exert protective effects on the new-born [189]. MFGMassociated bioactive components may influence the microbial composition of infants, which in turn, can induce protective effects on the CNS and the immune system via the gut-brain axis [189]. For instance, MFGM proteins lactadherin and mucin-1 have antimicrobial properties and modulate the binding of bacteria in the infant gut [190]. These proteins selectively promote the growth of commensals and obstruct the propagation of pathogens in the neonatal intestine [191].

The MFGM in human milk has been linked to cognitive and health benefits in humans [171] and rodents [192,193]. Sphingomyelin, phosphatidylcholine, and phosphatidylethanolamine are all highly present components of the MFGM, with choline as a common precursor of the neurotransmitter acetylcholine which is involved in the motor neuron activity of the autonomic nervous system [194], and is implicated in CNS functions such as arousal, attention and memory $[195,196]$. Nonetheless, acetylcholine together with folate and betaine are essential for early life CNS development as have been discussed in Sections 2.1 and 2.2.1. Sphingomyelins in the MFGM are especially important for myelination and have been shown to improve the neurobehavioral development of low-birth weight infants [197]. Recent studies have shown that MFGM supplementation ameliorated the visceral sensitivity and cognitive impacts of early life stress, in maternally separated rats compared to controls [193] and was able to partly improve spatial learning and memory [192]. The functional properties of the MFGM on infant cognitive and general development and health have been recently extensively reviewed elsewhere [165].

Human Milk Oligosaccharides and Sialic Acid

Human milk oligosaccharides (HMOs) such as 2-fucosyllactose and lacto-N-tetraose, are indigestible glycans that pass through the GI tract. HMOs composition is affected by maternal characteristics such as maternal BMI and geography [198], genetics [199] and diet [200]. In a recent study, a short-term dietary intervention in lactating mothers induced significant alterations in the HMO composition, showing that dietary choices during lactation impacts HMOs rapidly [200]. Upon reaching the intestines, HMOs are fermented by microbiota serving as prebiotics and, promoting microbial growth in a strainspecific manner [201]. For instance, Bifidobacterium infantis has a very specific preference to metabolize lacto-N-tetraose, but is also able to grow sufficiently in other HMOs [202], while various strains of Bacteroides have been found to digest only specific types of HMOs in vitro [203]. Therefore, the presence of different HMOs in human milk may induce different effects on the microbiota of each infant, depending on the strains that are already present in the gut, as well as in microbiota supplied by the breast milk [204].

More than 200 separate types of HMOs are present in maternal milk which have a protective action on the infant gut. They induce maturation of epithelial cells and improve gut barrier function, protecting the infant gut from infections and, promoting the viability and diversity of commensals [185]. A few clinical studies validated that HMOs presence promotes the growth of Bifidobacterium in the intestine, a genus that is abundant in the gut of breastfed infants [205-207]. Moreover, HMOs have protective properties against specific opportunistic pathogenic bacteria such as Salmonella, Listeria, and Campylobacter, by preventing those pathogens from attaching to the intestinal wall, hence forcing them to be excreted from the GI tract [184].

HMOs' action can also improve infant health and neurodevelopment via microbiotagut-brain axis. It has been recently suggested that there is a link between 2-fucosyllactose 
consumption, frequency of breastfeeding and cognitive development in 1-month old breastfed infants [187]. Moreover, HMO consumption has been linked to improved neurodevelopment and cognition in both clinical [208] and preclinical studies [209-211]. In rodents, 2-fucosyllactose supplementation improves hippocampal learning and memory formation [209], as well as enhances cognition all the way through adulthood [210].

HMO-associated sialic acid is another bioactive component of breast milk, that is more abundant in the early stages of lactation compared to term milk [212,213]. Sialic acid is known to promote cognition and neurodevelopment in animal models, and it is associated with gangliosides homeostasis in the CNS [212,214,215], as well as modulation of the microbiota in the gut [215]. Sialylated HMO supplementation improves learning and memory in piglets [216] and is associated with increased sialic acid concentration in brain regions linked to those cognitive changes [217]. Interestingly, sialylated HMO supplementation led to better cognitive outcomes compared to free sialic acid supplementation in rats [218]. Sialylated milk oligosaccharides are prebiotics that influence the microbiota composition in the infant [219] and the mouse intestine and reduce stress-induced anxiety like behaviour [220]. The beneficial effects of sialylated and non-sialylated HMOs present in breast milk are evident in the gut [185] and the brain [209-211] via the modulation of the microbiota-gut-brain axis signalling.

\section{Breast Milk Microbiota}

Even though breast milk was initially considered sterile, microbial metabolites were detected in the colostrum, which is the first milk produced after birth [201]. Intestinal microbial composition analysis of exclusively breast-fed neonates has shown greater abundance of Bifidobacterium and Bacteroides genera, compared to formula-fed infants [201,221-224]. This finding has led to two possible conclusions: that there is probable bacterial trafficking via breast milk to the neonate and/or that breast milk is a better substrate for particular commensals than commercial infant formula [201].

Various mechanisms have been proposed for microbiota transmission via breastfeeding such as (1) contact with maternal skin, (2) retrograde flow from the infant oral cavity to the ductal tissue and (3) enteromammary trafficking [201]. In order to investigate the first hypothesis, lactating women were advised to clean the areolar skin area before milk expression [120,225]. However, even after cleaning, enteric- and skin-related microbes were evident in the breast milk [120,225] justifying that there is another pathway of microbial flow in breast milk. The second hypothesis, called retrograde flow hypothesis, entails the flow of microbes from the infant oral cavity to the mammary gland. Even though retrograde flow of milk from the oral cavity to the ductal tissue is evident [226], certain microbes present in breast milk (such as Actinomyces, Bifidobacterium and Lactobacillus) are not present in the neonatal oral cavity before the onset of breastfeeding [225]. Therefore this hypothesis could justify the presence of some microbes in the ductal tissue from the neonatal oral cavity, but could not justify the complex composition of microbes found in breast milk [201]. Additionally, there are bacterial DNA traces present in the colostrum before the beginning of breastfeeding [120]. The third hypothesis, termed enteromammary trafficking includes the engulfment of intestinal maternal bacteria by mucosal intestinal dendritic cells, translocation of these cells via the circulatory or the lymphoid system to the mammary gland and, finally, transportation of microbiota via breast milk to the neonate [201]. Genomic data from three clinical studies suggest that there are common traces of Bifidobacterium longum, Bifidobacterium pseudocatenulatum and Streptococcus thermophilus in maternal stool, maternal blood, breast milk and infant stool samples highlighting the maternal-breast milk-infant link in the onset of infant microbiota [227-229]. Of the three hypotheses the latter is most plausible, as it also explains the presence of microbes already in the colostrum, even before the onset of breastfeeding [201].

Breast milk has a dynamic microbial assembly composed of mammary skin-, maternal gut- and neonatal oral-associated viable microorganisms with more than 200 different genera present [120], including Lactobacilli, Staphylococci, Streptococci and Bifidobacte- 
ria $[201,225,230]$. The microbial assembly of breast milk is highly influenced by maternal and infant factors such as maternal pregestational BMI, weight and diet, stage of lactation, mode of delivery as well as antibiotic exposure, infant gender and method of milk expression $[121,231,232]$.

For instance, a maternal Mediterranean diet led to increased abundance of Lactobacilli compared to Western diet, in the mammary glands of a non-human primate model [232]. In another recent human study maternal diet modified the HMO composition in breast milk and the metagenomic (but not taxonomic) landscape of milk bacteria as a response to dietary-related alterations of the HMOs in human milk [200]. These alterations in milk microbiota, link maternal nutrition to metabolic capacity of milk microbiota that are seeded to the infant gut. Maternal diet during lactation changes the metabolic capacity of her gut and breast milk microbiota that are subsequently seeded to the infant gut during lactation, leaving microbial and metabolic signatures during critical temporal windows of development [200].

As long as breastfeeding is maintained, breast milk microbiota is an endless supply of colonizing bacteria for the infant gut and exert their effects via the gut-brain axis on modulation of intestinal, neurological and behavioural functions in early life that could possibly imprint the CNS and immune system throughout the lifespan [5,121,233]. Diet remains the major regulator of both maternal and infant intestinal microbiota [63] as well as breast milk microbiota [121,200]. Some breastfeeding-related protective mechanisms on infants are also partially attributed to microbiota present in breast milk itself [121].

\subsubsection{Infant Formula}

Infant formula is a manufactured food designed for feeding children under 12 months of age. There are multiple reasons why infant formula feeding is a necessary alternative such as inability to breastfeed due to health issues or socioeconomic reasons (mother not present due to work, single parents etc). However, infant formula feeding is not recommended unless there is no other alternative, with breastfeeding being the first choice and breast milk from donors following in second place [234]. Infant formula production is highly regulated and is produced to resemble breast milk as much as possible with close attention paid to nutrient composition, bioactive components, taste and texture [60].

\section{Macronutrients in Infant Formula}

The macronutrient composition of infant formula has changed rapidly over the last decade. The majority of the constituent protein is derived from bovine milk, which is generally lower in quality compared to human milk proteins, primarily due to the limited amount of essential amino acids present in bovine milk [186]. The protein content of bovine-based infant formula ranges between $2-3 \mathrm{~g} / 100 \mathrm{~mL}$ [235], which is approximately two to three times higher compared to protein present in breast milk (ranges from $1.4-1.6 \mathrm{~g} / 100 \mathrm{~mL}$ in colostrum, $0.8-1.0 \mathrm{~g} / \mathrm{mL}$ in mature milk) [161]. Although the quantity of protein is very different between human milk and bovine-based infant formula, the most abundant proteins present are quite similar; casein and whey protein with ratio fluctuating from 2:1 to 4:1 in colostrum and 1:1 in mature breast milk [166] compared with ratio ranging between 5:1 to $4: 1$ in bovine-based infant formula [60,235]. Apart from standardizing the protein content to $1.8 \mathrm{~g} / 100 \mathrm{kcal}$ in infant formula [235], companies that produce formula now add proteins with bioactive effects, such as lactoferrin [236]. However, other types of proteins have been used in infant formula to cover the nutritional needs of the baby such as goat milk protein or plant-based proteins from soy bean or green peas [186]. While the gap between infant formula and breast milk is closing, not only in terms of protein content but also regarding carbohydrates, bioactive components (such as lactoferrin, HMOs and hormones), there is still a long way to go [186]. More research is needed to evaluate the mechanisms that the various components of infant formula impact on the health of children from infancy to adulthood, compared to breastfed infants. More detailed information about macronutrient composition in infant formula can be found in Table 4. 
Table 4. Macronutrients in infant formula and their effect in infant health.

\begin{tabular}{|c|c|c|c|c|c|}
\hline $\begin{array}{l}\text { Category of } \\
\text { Molecule }\end{array}$ & $\begin{array}{l}\text { Formula } \\
\text { Component }\end{array}$ & Effect on & Associated with & References & Population \\
\hline \multirow{3}{*}{ Protein } & \multirow{3}{*}{$\begin{array}{l}\text { Whey protein and } \\
\text { casein (cow-based } \\
\text { formula) }\end{array}$} & \multirow{3}{*}{$\begin{array}{l}\text { General growth } \\
\text { and development }\end{array}$} & $\begin{array}{l}\text { Weight gain in infancy and } \\
\text { higher adiposity later in life }\end{array}$ & [237] & $\begin{array}{l}\text { Humans: } \\
\text { Caucasian }\end{array}$ \\
\hline & & & Allergies in milk protein & {$[60]$} & $\begin{array}{l}\text { Humans: multiple, } \\
\text { mice and rats }\end{array}$ \\
\hline & & & $\begin{array}{l}\text { Higher secretion of insulin } \\
\text { due to stimulation of } \\
\beta \text {-pancreatic cells by } \\
\text { amino-acids }\end{array}$ & [237] & $\begin{array}{l}\text { Humans: } \\
\text { Caucasian }\end{array}$ \\
\hline \multirow{3}{*}{ Fat } & $\begin{array}{l}\text { Mixed vegetable } \\
\text { oils (DHA \& ARA) }\end{array}$ & $\begin{array}{c}\text { Adipocyte } \\
\text { stimulation and fat } \\
\text { storage }\end{array}$ & $\begin{array}{l}\text { High consumption of } \omega-6 \\
\text { fatty acids might induce } \\
\text { adiposity in early life }\end{array}$ & {$[186,238]$} & $\begin{array}{l}\text { Humans: multiple, } \\
\text { mice and rats }\end{array}$ \\
\hline & \multirow{2}{*}{$\begin{array}{l}\text { MFGM (cow-based } \\
\text { formula) }\end{array}$} & $\begin{array}{l}\text { Fat storage and } \\
\text { general } \\
\text { metabolism }\end{array}$ & $\begin{array}{l}\text { Decreased fat accumulation, } \\
\text { concentrations of leptin, } \\
\text { glucose and lipids in plasma }\end{array}$ & [239] & Mice \\
\hline & & $\begin{array}{c}\text { Cognitive } \\
\text { development }\end{array}$ & $\begin{array}{l}\text { Improves cognition of } \\
\text { formula-fed infants }\end{array}$ & [171] & $\begin{array}{l}\text { Humans: } \\
\text { Caucasians }\end{array}$ \\
\hline Carbohydrates & Lactose & $\begin{array}{l}\text { General growth } \\
\text { and development }\end{array}$ & Low gastrointestinal tolerance & [240] & Humans: multiple \\
\hline
\end{tabular}

Prebiotics, Probiotics and Synbiotics in Infant Formula

Health benefits of HMOs present in human milk on the intestine, the diversity of commensals, the immune and the central nervous systems incentivised infant formulaproducing companies to supplement formulas with prebiotics in order to narrow the gap between human milk and infant formula [241]. Prebiotics supplementation is predominantly done with addition of short-chain galacto-oligosaccharides (scGOS) and long-chain fructo-oligosaccharides (lcFOS) which are both efficiently metabolized by Bifidobacterium, contrary to the HMOs present in human milk that are only partly metabolized by this genus [242]. Two other HMOs that have been more recently added to infant formula are 2 -fucosyllactose and Lacto-N-neotetraoze [243]. Consumption of fortified infant formula with these two prebiotics led to a similar composition of faecal microbiota between formulafed and breastfed infants at 3 months of age [243], but this effect disappeared by 12 months of age [187].

Prebiotic supplementation of infant formula led to significantly altered microbiota composition in infants compared to non-supplemented control infant formula [244] and has been recently reviewed elsewhere [245]. However, it is worth mentioning that counts of Bifidobacterium [246,247] and Lactobacillus [247] were found to increase with prebiotic supplementation. On the other hand, a decrease of specific pathogens (such as Escherichia coli, Enterococcus and Clostridium) was evident in faecal samples of 3-month-old infants receiving prebiotic supplemented infant formula compared to infants that received nonsupplemented one $[243,245]$. Supplementation of infant formula with prebiotics led to weight gain compared to non-supplemented one, but had no effect on height or head circumference in children, which are indications of growth [244,248].

In order to maximize the advantages of prebiotics, combined prebiotic mixtures with different genera of bacteria (largely Bifidobacterium and Lactobacillus strains), have been developed in order to create infant formula as close as possible to human milk $[186,249]$. Even though supplementation of infant formula with prebiotics is becoming more and more common, there are difficulties in mimicking the structural and physiological complexity of HMOs [186]. 
Supplementation of infant formula with synbiotics (prebiotic and probiotics) is an intricate process which has difficulty in mirroring the unique combination and complexity of ingredients present in breast milk [244,249]. The prevailing ideology of synbiotics supplementation is that prebiotics can be specifically tailored for the probiotics within the same mixture, therefore the synergistic effect of the two would possibly exert health benefits that are similar to the ones of breast milk microbiota and HMOs in breast milk [244]. Most synbiotics contain a mixture of GOS and FOS together with strains of Bifidobacterium and Lactobacillus [186] (see Table 5). So far, limited clinical data collected has shown that there was no effect of synbiotic supplementation in infant formula on child development [244,250-252]. Hence, more research is needed to examine the possible effect of synbiotic fortification in infant formula on short- and long-term infant growth and health. Of note a promising study in rural Indian new-borns revealed significant reduction on sepsis and death levels of new-borns who were treated with a synbiotic mixture of Lactobacillus plantarum and FOS compared to untreated controls [253].

Table 5. Components of infant formula in order to simulate the synbiotic potential of human milk.

\begin{tabular}{|c|c|c|c|c|c|}
\hline $\begin{array}{l}\text { Category of } \\
\text { Molecule }\end{array}$ & Formula Component & Effect on & Associated with & References & Population \\
\hline \multirow[t]{2}{*}{ HMOs } & $\begin{array}{l}\text { Short-chain galacto- } \\
\text { oligosaccharides } \\
\text { (scGOS) and long-chain } \\
\text { fructo-oligosaccharides } \\
\text { (lcFOS) }\end{array}$ & $\begin{array}{l}\text { Highly metabolized by } \\
\text { Bifidobacteria, } \\
\text { contrary to the HMOs } \\
\text { present in human milk } \\
\text { that are only partly } \\
\text { metabolized by } \\
\text { Bifidobacteria }\end{array}$ & \multirow{2}{*}{$\begin{array}{l}\text { Weight gain but had } \\
\text { no effect on height or } \\
\text { head circumference, } \\
\text { significantly altered } \\
\text { microbiota } \\
\text { composition in infants }\end{array}$} & [242] & Humans: multiple \\
\hline & $\begin{array}{l}\text { 2-fucosyllactose }\left(2^{\prime} \mathrm{FL}\right) \\
\text { and Lacto-N-neotetraoze } \\
\text { (LNnT) }\end{array}$ & $\begin{array}{l}\text { Similar composition of } \\
\text { faecal microbiota } \\
\text { between formula-fed } \\
\text { and breastfed infants } \\
\text { at } 3 \text { months of age }\end{array}$ & & [243] & $\begin{array}{l}\text { Humans: multiple, } \\
\text { mice and In vitro }\end{array}$ \\
\hline Synbiotics & $\begin{array}{c}\text { GOS and FOS together } \\
\text { with strains of } \\
\text { Bifidobacteria and } \\
\text { Lactobacilli }\end{array}$ & $\begin{array}{c}\text { No effect on child } \\
\text { development }\end{array}$ & & [250-252] & $\begin{array}{l}\text { Humans: Asian, } \\
\text { Caucasian }\end{array}$ \\
\hline
\end{tabular}

\section{Infant Formula, Risks and Health Concerns}

Infant formula-fed infants have a faster growth curve that correlates with higher weight gain, advanced adiposity, and a higher risk of childhood obesity compared to age-matched breastfed infants [201]. Interestingly, infant formula consumption leaves a signature on glucose metabolism and insulin sensitivity, that persists to adulthood [254]. High insulin levels in formula-fed infants and its respective advanced adiposity in early life are correlated with high protein levels (2.9-4.4 g/100 kcal) found in high-protein infant formulas [255]. The timing at which formula is introduced to the infant is also a determinant of health in the neonatal period and adulthood; introduction of infant formula before the third month of life is correlated with increased risk of rapid growth at six months and high body mass index in adulthood [256]. Allergies are also prevalent among infants consuming infant formula, mainly due to sensitivity against casein or $\beta$-lactalbumin present in bovine milk [60].

Neonatal nutrition is a determining component of health in the early days and its effect remains throughout life. Improvement of structural and functional properties of formulas to minimize the differences between breastfed and formula-fed infants is strongly supported by research on infant formula. More independent research is important to reach conclusive results regarding the short- and long-term effects of the components of infant 
formula on human health, as well as the causation of the differences between formula-fed and breast-fed infants [186]. It is important to understand and distinguish correlation and causation, as well as the complexity of factors influencing these early life experiences.

\section{Microbiota Changes and Neurodevelopment: From Infancy to Childhood}

\subsection{Microbiota Maturation and Brain Development during Weaning}

In humans, the gradual introduction of solid food and the progressive termination of breastfeeding starts between 4-6 months after birth and is called weaning [257]. During this period, in order to cover the nutritional needs of the baby, parents might choose to complement the diet with infant formula or introduce solid food progressively. Solid food introduction is a major modifier of microbiota composition in the gut and it dictates the beginning of intestinal microbiota maturation [258]. This microbiota maturation is gradual, reaching a more diverse, yet stable composition [245].

Introduction of solid foods during the transition from a milk-based to a more complex adult-like diet, changes the richness and diversity of the microbiota landscape $[245,258]$. During this change in food substrates, counts of milk-related bacteria are reduced and genera able to digest more complex nutrients are expanding. For instance, certain genera such as Lachnospiraceae, Ruminococcaceae, Blautia, Bacteroides, and Akkermansia are blooming [258], while Bifidobacterium, Veillonellaceae, Lactobacillaceae, Enterobacteriaceae, and Enterococcaceae counts are gradually decreased [258]. As long as the early feeding mode (breast- or formula feeding) continues to be present, the microbiota landscape displays an in-between state of the infant and the adult compositions [34].

Throughout those substrate changes during weaning, the microbiota's metabolic capacity also shifts in the infant gut with increasing genes linked to complex polysaccharide metabolism such as starch [259]. Nutrition is a major modulator of microbiota colonization and propagation in the intestine [63], and therefore, their respective microbial signals are crucial for healthy development of neuronal circuits in the brain, as well as for behavioural imprinting [9]. The nutritional changes during the solid food introduction period coincides with the sensitive developmental period around weaning (see Figure 2). However, more clinical studies are needed to investigate the microbial changes during weaning and their long-term effects in humans.

Increased emphasis is being placed on the role of the microbiota in gating immunological changes to weaning [164]. The implications this has for brain function is currently unknown. However, given that microbiota maturation in the infant gut coincides with postnatal brain development $[9,59]$ such as synapse propagation and pruning [78] it is highly likely to be relevant. Neurons are highly plastic in response to environmental stimuli during windows of opportunity, such as the postnatal period, resulting in irreversible changes that persist throughout life [79]. It is hypothesized that the intestinal microbiota has a role in structural and functional aspects of brain development and maturation [42,106]. Indeed, the total absence of microbiota in GF animals led to structural alterations in the brain, with GF animals having lower density and length of dendritic spines as well as enlarged amygdala and hippocampi compared to conventional mice [260].

\subsection{Solid Food Introduction and Establishment of Nutritional Habits}

Dietary habits of the mother during pregnancy and food choices early in life are known to be essential for the establishment of odours and taste preferences in later life [261]. The olfactory system, which includes the olfactory bulbs in the brain that are responsible for taste and smell perception, is functional already at the 24th week of gestation [262]. The amniotic fluid is full of nutrients from maternal diet and stores and, it is the first 'food' the fetus is able to detect different tastes and flavours from [263]. Behavioural mechanisms, such as programming of food preferences and eating behaviour start very early in life and have been recently discussed elsewhere [264].

During the initial years after birth the seeded microbiota continues to develop and mature with multiple factors such as nutrition, environmental and maternal factors, dictat- 
ing its propagation in critical temporal windows of development. For instance, perinatal factors such as delivery mode or gestational age at birth have been recently unravelled as determinants of the gut microbiota composition up to four years of age in humans [118]. These findings suggest that events that disturb normal microbial seeding perinatally might leave signatures in the first steps of life, and it is therefore hypothesized that early life microbial perturbations possibly prime developmental processes which tip the balance between health and disease.

\section{Early Life Microbiota: Another Component in the Vicious Cycle of Malnutrition}

Malnutrition is an umbrella term and in its whole spectrum includes undernutrition (wasting, stunting, underweight), overweight and obesity and remains a global health challenge up until today [265]. Apart from extreme undernutrition, moderate caloric and nutrient restriction during pregnancy (self-imposed maternal dieting or teenage pregnancy) is common in developing and developed countries [266]. The consistently decreased exposure to proper quantity and quality of food during pregnancy can lead to irreversible changes in crucial body systems such as the CNS [267], cardiovascular [268], haemopoietic [269] and immune system [270] of the developing fetus.

The nutrient availability for the developing fetus depends on the concentration of those nutrients in maternal circulation and the blood flow in the placenta that will distribute them to the embryo [271]. After birth, the most prominent factors for the onset of severe acute early life malnutrition are the abnormal or early cessation of breastfeeding, premature weaning and low-quality of breast milk due to disturbed maternal nutritional and general health status [272].

\subsection{Undernutrition and CNS Development}

During pregnancy, even mild or moderate caloric restriction could have a dramatic impact on the fate of CNS development. In a non-human primate model, moderate caloric restriction in the mother led to decreased cerebral development, neurotrophic factor suppression, impaired axonal growth and glial maturation in the offspring [273]. In the same study, decreased maternal nutrient availability resulted in downregulation of transcriptome pathways related to brain development and cell proliferation of the embryo, while pathways related to cerebral catabolism and cell death were significantly upregulated [273].

In rodents, reduced maternal protein intake during pregnancy ( 5 or $10 \%$ protein as compared to $20 \%$ protein) caused not only impairments in brain development and growth rate of the pups, but also in protein and fatty acid metabolism, in the brain and on a whole-body level [274]. In another similar rodent study, dam exposure to a low-protein diet during pregnancy through 4 weeks postnatally, resulted in decreased BDNF gene expression levels in the hippocampus of the offspring accompanied by impaired spatial learning and memory [275]. Moderate nutritional/caloric restriction during pregnancy impacts brain metabolism [274], and gene and protein expression of key-regulators for CNS health, and affects cerebral development of the embryo which leads to behavioural adversities later in life, in preclinical models [275].

In humans, insufficient early life energy, protein iron and iodine intake leads to impaired behavioural and cognitive function that persist to adulthood. Deficiency of B vitamins, zinc, betaine and choline are able to induce irreversible changes in the brain and lead to neurological deficits on the developing child $[87,276]$. During the infamous period of the Dutch famine in the mid-1940s, when exposure to nutrients was widely insufficient, the malnutrition cases were extremely high [276]. Birth cohorts and later follow-up studies showed that pre- and perinatal malnutrition increased the prevalence of congenital disease of the CNS in early life, schizophrenia and schizophrenia spectrum personality disorders in adults that were exposed to the famine as infants. Malnutrition or undernutrition during crucial developmental time-windows, for instance during synapse formation, could lead to impaired brain growth with no or possible minimal recovery 
after nutritional rehabilitation at a later time-point $[86,277]$. Recovery is possible only after nutritional rehabilitation before the end of the critical period of synapse formation, proliferation and brain growth [278].

\subsection{Undernutrition and Microbiota}

Optimal nutrition in early life is crucial for the expansion of the microbiota, immune system development, and the balance of host-microbe interactions. Exposure of 3-week-old mice to reduced dietary protein resulted in decreased binding of intestinal immunoglobulin A ( $\operatorname{IgA}$ ) with commensal bacteria, interfering with normal mucosal processes in the mouse intestine [63]. This disrupted relationship between IgA and gut commensals led to adaptation of bacteria to nutrient limitation and modulated the host-microbial homeostasis by reducing the binding of commensals on the intestinal mucosa [63]. In another similar preclinical study, dietary intervention with tryptophan-deficient diet in mice led to vitamin B3 deficiency which modulates the production of antimicrobial peptides in the intestine [279]. This dietary intervention led to altered microbiota composition accompanied by inflammatory colitis attributed to the microbial composition changes [279]. Therefore, postnatally and during time-windows of opportunity such as weaning, undernutrition regulates important homeostatic host-microbe interactions.

In severely malnourished children it is difficult to identify whether the changes in gut microbiota composition present as a consequence of the diet or the condition or the combination of both [272]. A common complication in severely malnourished children is enteric septicaemia with increase prevalence of Salmonella, Shigella and Staphylococcus aureus populations in faecal samples [280]. These bacteria were able to grow in blood cultures, suggesting that in the presence of a leaky gut, a common outcome in undernourished populations, the pathogens possibly survive and migrate to other previously sterile tissues via the systemic circulation [280].

Microbiota composition in malnourished children is disturbed with almost depleted Bifidobacterium and an inverted aerobes:anaerobes ratio in faecal samples resembling a non-mature microbiota $[181,281]$. Nutritional intervention alone is unable to inverse the unhealthy aerobes:anaerobes ratio, suggesting that diet alone is unable to modulate the unhealthy microbiota after it has been established in critical temporal windows during early life [281]. Interestingly, antibiotic treatment with cefdinir and amoxicillin has shown promising results in systemic treatment of malnourished children, by decreasing the incidence of diarrhoea and mortality while promoting weight gain [280]. Antibiotic treatment accompanied by therapeutic diet and probiotic supplementation with Lactobacillus delbrueckii effectively reduced mortality of malnourished children [280]. The combination of antibiotics together with high-quality protein and high-fibre diet (prebiotic) as well as supplementation with probiotic bacteria might be a more targeted approach to malnutrition [272].

Recent approaches have focused on targeting the microbiome for undernourished children via societal strategies such as educational support highlighting the importance of the microbiota on high-risk communities [282] and promotion of microbiota-directed complementary foods that aim at the maturation of the stunted-like, immature microbiota, present in the intestine of those individuals [282,283]. Even though studies on undernutrition usually focus on general child development, links between microbiota and brain developmental changes induced by malnutrition have also been highlighted [61].

Poverty and food insecurity are major risk factors for malnutrition [284]. However, malnutrition is a complex condition and very difficult to reproduce in controlled, hygienic environments [285]. It is hypothesized that apart from the decreased nutrient availability, severe acute malnutrition has a microbial component [285]. The decreased availability of nutrients might lead to altered microbiota composition and increased inflammation in the gut that subsequently modulates the intestinal environment, the absorption of nutrients and magnifies the microbial dysbiosis in the gut $[282,284]$. Therefore, the vicious cycle of 
malnutrition has another intestinal microbial component that could partly act as a target for prevention of symptoms of the disease.

\section{Conclusions}

Microbes are co-existing and co-evolving with humans across the lifespan and it is believed that the beginning of this mutualistic relationship starts at birth. However, increasing data has shown that microbial signatures modulate embryonic development, imprint the CNS and the immune system and fine-tune the balance between health and disease. Both neurodevelopment and microbial composition in early life are plastic and influenced by parental (genetics, diet, internal stores, pathophysiology of the parents, delivery mode, feeding mode, establishment of nutritional habits) and environmental (infections, antibiotics, pollution) factors.

Early life nutrition plays a central role in the onset of multiple developmental processes in the brain and the alimentary canal via nutritional programming and modulation of the microbiota-gut-brain axis during the first steps of life, regulating the equilibrium between health and disease later in life. Understanding the link between the triad of perinatal nutrition, neurodevelopment and gut microbiota is of great importance in order to unravel the mechanisms of diseases that are believed to be rooted in early life. Although important data has recently described some of the early life nutritional programming and the microbial contribution on the imprinting of the CNS, principal mechanisms remain elusive. Perturbations that challenge the balance of this relationship during critical temporal windows of development might disturb gut homeostasis and host-microbial interactions, as well as structural and functional alterations in the CNS. More research is essential on the impact of nutrition on the shaping of the gut microbiota and neurodevelopment of the offspring to untangle the intertwined pieces of this complex puzzle that is microbiota-gutbrain axis and, to possibly prevent, diagnose and mitigate conditions that are rooted in this sensitive period.

Funding: M.G.C. was funded by the European Union's Horizon 2020 research and innovation programme under the Marie Sklodowska-Curie grant agreement No 754535. This research was funded by Science Foundation Ireland (SFI/12/RC/2273). APC Microbiome Ireland has conducted research funded by several Pharmaceutical and Food companies. Publication expenses for this article has been supported by Cátedra ORDESA-University of Granada, Spain as part of Special Issue "Early Nutrition and Re-programming of Health and Disease".

Institutional Review Board Statement: Not applicable.

Informed Consent Statement: Not applicable.

Data Availability Statement: No data are produced in this study, it is only reviewing of existing data.

Acknowledgments: We thank Gabriel Tofani, Kenneth O'Riordan and Gerard Moloney for their assistance and support.

Conflicts of Interest: J.F.C. has been an invited speaker at meetings organized by Cátedra ORDESAUniversity of Granada, Neuropharmex, Mead Johnson, Friesland Campina, has been a consultant for Nestle \& Alkermes and has received research funding from Mead Johnson, Cremo, Suntory Wellness, Nutricia and 4D Pharma.

\section{References}

1. Dominguez-Bello, M.G.; Costello, E.K.; Contreras, M.; Magris, M.; Hidalgo, G.; Fierer, N.; Knight, R. Delivery mode shapes the acquisition and structure of the initial microbiota across multiple body habitats in newborns. Proc. Natl. Acad. Sci. USA 2010, 107, 11971-11975. [CrossRef] [PubMed]

2. Borre, Y.E.; O'Keeffe, G.W.; Clarke, G.; Stanton, C.; Dinan, T.G.; Cryan, J.F. Microbiota and neurodevelopmental windows: Implications for brain disorders. Trends Mol. Med. 2014, 20, 509-518. [CrossRef] [PubMed]

3. Milani, C.; Duranti, S.; Bottacini, F.; Casey, E.; Turroni, F.; Mahony, J.; Belzer, C.; Palacio, S.D.; Montes, S.A.; Mancabelli, L.; et al. The First Microbial Colonizers of the Human Gut: Composition, Activities, and Health Implications of the Infant Gut Microbiota. Microbiol. Mol. Biol. Rev. 2017, 81, e00036-17. [CrossRef] [PubMed]

4. Ursell, L.K.; Metcalf, J.L.; Parfrey, L.W.; Knight, R. Defining the human microbiome. Nutr. Rev. 2012, 70, S38-S44. [CrossRef] 
5. Pannaraj, P.S.; Li, F.; Cerini, C.; Bender, J.M.; Yang, S.; Rollie, A.; Adisetiyo, H.; Zabih, S.; Lincez, P.J.; Bittinger, K.; et al. Association Between Breast Milk Bacterial Communities and Establishment and Development of the Infant Gut Microbiome. JAMA Pediatr. 2017, 171, 647-654. [CrossRef]

6. Dierikx, T.; Visser, D.; Benninga, M.; Van Kaam, A.; De Boer, N.; De Vries, R.; Van Limbergen, J.; De Meij, T. The influence of prenatal and intrapartum antibiotics on intestinal microbiota colonisation in infants: A systematic review. J. Infect. 2020, 81, 190-204. [CrossRef]

7. Rhee, S.H.; Pothoulakis, C.; Mayer, E.A. Principles and clinical implications of the brain-gut-enteric microbiota axis. Nat. Rev. Gastroenterol. Hepatol. 2009, 6, 306. [CrossRef]

8. Collins, S.M.; Surette, M.G.; Bercik, P. The interplay between the intestinal microbiota and the brain. Nat. Rev. Genet. 2012, 10, 735-742. [CrossRef]

9. Cryan, J.F.; O’Riordan, K.J.; Cowan, C.S.M.; Sandhu, K.V.; Bastiaanssen, T.F.S.; Boehme, M.; Codagnone, M.G.; Cussotto, S.; Fulling, C.; Golubeva, A.V.; et al. The Microbiota-Gut-Brain Axis. Physiol. Rev. 2019, 99, 1877-2013. [CrossRef]

10. Morais, L.H.; Iv, H.L.S.; Mazmanian, S.K. The gut microbiota-brain axis in behaviour and brain disorders. Nat. Rev. Genet. 2020, 1-15. [CrossRef]

11. Konturek, S.J.; Konturek, J.W.; Pawlik, T.; Brzozowski, T. Brain-gut axis and its role in the control of food intake. J. Physiol. Pharmacol. Off. J. Pol. Physiol. Soc. 2004, 55, 137-154.

12. Berthoud, H.-R. Vagal and hormonal gut-brain communication: From satiation to satisfaction. Neurogastroenterol. Motil. 2008, 20, 64-72. [CrossRef] [PubMed]

13. Breit, S.; Kupferberg, A.; Rogler, G.; Hasler, G. Vagus Nerve as Modulator of the Brain-Gut Axis in Psychiatric and Inflammatory Disorders. Front. Psychiatry 2018, 9, 44. [CrossRef] [PubMed]

14. Bercik, P.; Verdu, E.F.; Foster, J.A.; Macri, J.; Potter, M.; Huang, X.; Malinowski, P.; Jackson, W.; Blennerhassett, P.; Neufeld, K.A.; et al. Chronic Gastrointestinal Inflammation Induces Anxiety-Like Behavior and Alters Central Nervous System Biochemistry in Mice. Gastroenterolgy 2010, 139, 2102-2112.e2101. [CrossRef] [PubMed]

15. Kennedy, P.J.; Clarke, G.; Quigley, E.M.; Groeger, J.A.; Dinan, T.G.; Cryan, J.F. Gut memories: Towards a cognitive neurobiology of irritable bowel syndrome. Neurosci. Biobehav. Rev. 2012, 36, 310-340. [CrossRef]

16. Bercik, P.; Denou, E.; Collins, J.; Jackson, W.; Lu, J.; Jury, J.; Deng, Y.; Blennerhassett, P.; Macri, J.; McCoy, K.D.; et al. The Intestinal Microbiota Affect Central Levels of Brain-Derived Neurotropic Factor and Behavior in Mice. Gastroenterology 2011, 141, 599-609.e593. [CrossRef]

17. Heijtz, R.D.; Wang, S.; Anuar, F.; Qian, Y.; Björkholm, B.; Samuelsson, A.; Hibberd, M.L.; Forssberg, H.; Pettersson, S. Normal gut microbiota modulates brain development and behavior. Proc. Natl. Acad. Sci. USA 2011, 108, 3047-3052. [CrossRef]

18. Spichak, S.; Guzzetta, K.E.; O'Leary, O.F.; Clarke, G.; Dinan, T.G.; Cryan, J.F. Without a bug's life: Germ-free rodents to interrogate microbiota-gut-neuroimmune interactions. Drug Discov. Today Dis. Model. 2018, 28, 79-93. [CrossRef]

19. Verdu, E.F.; Bercik, P.; Verma-Gandhu, M.; Huang, X.-X.; Blennerhassett, P.; Jackson, W.; Mao, Y.; Wang, L.; Rochat, F.; Collins, S.M. Specific probiotic therapy attenuates antibiotic induced visceral hypersensitivity in mice. Gut 2006, 55, 182-190. [CrossRef]

20. O'Mahony, S.; Felice, V.; Nally, K.; Savignac, H.; Claesson, M.; Scully, P.; Woznicki, J.; Hyland, N.; Shanahan, F.; Quigley, E.; et al. Disturbance of the gut microbiota in early-life selectively affects visceral pain in adulthood without impacting cognitive or anxiety-related behaviors in male rats. Neuroscience 2014, 277, 885-901. [CrossRef]

21. Keogh, C.E.; Kim, D.H.; Pusceddu, M.M.; Knotts, T.A.; Rabasa, G.; Sladek, J.A.; Hsieh, M.T.; Honeycutt, M.; Brust-Mascher, I.; Barboza, M.; et al. Myelin as a regulator of development of the microbiota-gut-brain axis. Brain Behav. Immun. 2021, 91, 437-450. [CrossRef] [PubMed]

22. Korpela, K.; Salonen, A.; Virta, L.J.; Kumpu, M.; Kekkonen, R.A.; De Vos, W.M. Lactobacillus rhamnosus GG Intake Modifies Preschool Children's Intestinal Microbiota, Alleviates Penicillin-Associated Changes, and Reduces Antibiotic Use. PLoS ONE 2016, 11, e0154012. [CrossRef] [PubMed]

23. Firestein, M.R.; Myers, M.M.; Austin, J.; Stark, R.I.; Barone, J.L.; Ludwig, R.J.; Welch, M.G. Perinatal antibiotics alter preterm infant EEG and neurobehavior in the Family Nurture Intervention trial. Dev. Psychobiol. 2019, 61, 661-669. [CrossRef] [PubMed]

24. Long-Smith, C.; O’Riordan, K.J.; Clarke, G.; Stanton, C.; Dinan, T.G.; Cryan, J.F. Microbiota-Gut-Brain Axis: New Therapeutic Opportunities. Annu. Rev. Pharmacol. Toxicol. 2020, 60, 477-502. [CrossRef] [PubMed]

25. Yassour, M.; Vatanen, T.; Siljander, H.; Hämäläinen, A.-M.; Härkönen, T.; Ryhänen, S.J.; Franzosa, E.A.; Vlamakis, H.; Huttenhower, C.; Gevers, D. Natural history of the infant gut microbiome and impact of antibiotic treatment on bacterial strain diversity and stability. Sci. Transl. Med. 2016, 8, 343ra381. [CrossRef]

26. Lupp, C.; Robertson, M.L.; Wickham, M.E.; Sekirov, I.; Champion, O.L.; Gaynor, E.C.; Finlay, B.B. Host-Mediated Inflammation Disrupts the Intestinal Microbiota and Promotes the Overgrowth of Enterobacteriaceae. Cell Host Microbe 2007, 2, 119-129. [CrossRef]

27. Dinan, T.G.; Cryan, J.F. Gut instincts: Microbiota as a key regulator of brain development, ageing and neurodegeneration. J. Physiol. 2016, 595, 489-503. [CrossRef]

28. Bailey, M.T.; Dowd, S.E.; Galley, J.D.; Hufnagle, A.R.; Allen, R.G.; Lyte, M. Exposure to a social stressor alters the structure of the intestinal microbiota: Implications for stressor-induced immunomodulation. Brain Behav. Immun. 2011, 25, 397-407. [CrossRef] 
29. David, L.A.; Maurice, C.F.; Carmody, R.N.; Gootenberg, D.B.; Button, J.E.; Wolfe, B.E.; Ling, A.V.; Devlin, A.S.; Varma, Y.; Fischbach, M.A.; et al. Diet rapidly and reproducibly alters the human gut microbiome. Nat. Cell Biol. 2014, 505, 559-563. [CrossRef] [PubMed]

30. Allais, L.; Kerckhof, F.-M.; Verschuere, S.; Bracke, K.R.; De Smet, R.; Laukens, D.; Abbeele, P.V.D.; De Vos, M.; Boon, N.; Brusselle, G.G.; et al. Chronic cigarette smoke exposure induces microbial and inflammatory shifts and mucin changes in the murine gut. Environ. Microbiol. 2015, 18, 1352-1363. [CrossRef] [PubMed]

31. Levin, A.; Sitarik, A.R.; Havstad, S.L.; Fujimura, K.E.; Wegienka, G.; Cassidy-Bushrow, A.E.; Kim, H.; Zoratti, E.M.; Lukacs, N.W.; Boushey, H.A.; et al. Joint effects of pregnancy, sociocultural, and environmental factors on early life gut microbiome structure and diversity. Sci. Rep. 2016, 6, 31775. [CrossRef] [PubMed]

32. Lynch, S.V.; Pedersen, O. The Human Intestinal Microbiome in Health and Disease. N. Engl. J. Med. 2016, 375, 2369-2379. [CrossRef] [PubMed]

33. Jin, Y.; Wu, S.; Zeng, Z.; Ota, T. Effects of environmental pollutants on gut microbiota. Environ. Pollut. 2017, 222, 1-9. [CrossRef] [PubMed]

34. Rodríguez, J.M.; Murphy, K.; Stanton, C.; Ross, R.P.; Kober, O.I.; Juge, N.; Avershina, E.; Rudi, K.; Narbad, A.; Jenmalm, M.C.; et al. The composition of the gut microbiota throughout life, with an emphasis on early life. Microb. Ecol. Heal. Dis. 2015, 26, 26050. [CrossRef]

35. Mayer, E.A.; Padua, D.; Tillisch, K. Altered brain-gut axis in autism: Comorbidity or causative mechanisms? BioEssays 2014, 36, 933-939. [CrossRef]

36. Needham, B.D.; Tang, W.; Wu, W.-L. Searching for the gut microbial contributing factors to social behavior in rodent models of autism spectrum disorder. Dev. Neurobiol. 2018, 78, 474-499. [CrossRef]

37. Liu, F.; Li, J.; Wu, F.; Zheng, H.; Peng, Q.; Zhou, H. Altered composition and function of intestinal microbiota in autism spectrum disorders: A systematic review. Transl. Psychiatry 2019, 9, 1-13. [CrossRef]

38. Lavebratt, C.; Yang, L.L.; Giacobini, M.; Forsell, Y.; Schalling, M.; Partonen, T.; Gissler, M. Early exposure to antibiotic drugs and risk for psychiatric disorders: A population-based study. Transl. Psychiatry 2019, 9, 1-12. [CrossRef]

39. Persaud, R.R.; Azad, M.B.; Chari, R.S.; Sears, M.R.; Becker, A.B.; Kozyrskyj, A.L.; Laprise, C. Perinatal antibiotic exposure of neonates in Canada and associated risk factors: A population-based study. J. Matern. Neonatal Med. 2015, 28, 1190-1195. [CrossRef]

40. Delara, M.; McMillan, D.E.; Nickel, N.C.; Jong, G.W.; Seitz, D.P.; Mignone, J. Early life exposure to antibiotics and the risk of mood and anxiety disorders in children and adolescents: A population-based cohort study. J. Psychiatr. Res. 2020. [CrossRef]

41. Mayer, E.A. Gut feelings: The emerging biology of gut-brain communication. Nat. Rev. Neurosci. 2011, 12, 453-466. [CrossRef] [PubMed]

42. Codagnone, M.G.; Stanton, C.; O’Mahony, S.M.; Dinan, T.G.; Cryan, J.F. Microbiota and Neurodevelopmental Trajectories: Role of Maternal and Early-Life Nutrition. Ann. Nutr. Metab. 2019, 74, 16-27. [CrossRef] [PubMed]

43. Conlon, M.A.; Bird, A.R. The impact of diet and lifestyle on gut microbiota and human health. Nutrients 2015, 7, 17-44. [CrossRef] [PubMed]

44. Efeyan, A.; Comb, W.C.; Sabatini, D.M. Nutrient-sensing mechanisms and pathways. Nat. Cell Biol. 2015, 517, 302-310. [CrossRef]

45. Hirasawa, A.; Tsumaya, K.; Awaji, T.; Katsuma, S.; Adachi, T.; Yamada, M.; Sugimoto, Y.; Miyazaki, S.; Tsujimoto, G. Free fatty acids regulate gut incretin glucagon-like peptide-1 secretion through GPR120. Nat. Med. 2005, 11, 90-94. [CrossRef]

46. Davani-Davari, D.; Negahdaripour, M.; Karimzadeh, I.; Seifan, M.; Mohkam, M.; Masoumi, S.J.; Berenjian, A.; Ghasemi, Y. Prebiotics: Definition, Types, Sources, Mechanisms, and Clinical Applications. Foods 2019, 8, 92. [CrossRef]

47. Silva, Y.P.; Bernardi, A.; Frozza, R.L. The Role of Short-Chain Fatty Acids from Gut Microbiota in Gut-Brain Communication. Front. Endocrinol. 2020, 11, 25. [CrossRef]

48. Stilling, R.M.; Van De Wouw, M.; Clarke, G.; Stanton, C.; Dinan, T.G.; Cryan, J.F. The neuropharmacology of butyrate: The bread and butter of the microbiota-gut-brain axis? Neurochem. Int. 2016, 99, 110-132. [CrossRef]

49. Fung, T.C.; Olson, C.A.; Hsiao, E.Y. Interactions between the microbiota, immune and nervous systems in health and disease. Nat. Neurosci. 2017, 20, 145-155. [CrossRef]

50. Arpaia, N.; Campbell, C.; Fan, X.; Dikiy, S.; Van Der Veeken, J.; DeRoos, P.; Liu, H.; Cross, J.R.; Pfeffer, K.; Coffer, P.J.; et al. Metabolites produced by commensal bacteria promote peripheral regulatory T-cell generation. Nature 2013, 504, 451-455. [CrossRef]

51. Smith, P.M.; Howitt, M.R.; Panikov, N.; Michaud, M.; Gallini, C.A.; Bohlooly-Y, M.; Glickman, J.N.; Garrett, W.S. The Microbial Metabolites, Short-Chain Fatty Acids, Regulate Colonic Treg Cell Homeostasis. Science 2013, 341, 569-573. [CrossRef] [PubMed]

52. Shokryazdan, P.; Jahromi, M.F.; Navidshad, B.; Liang, J.B. Effects of prebiotics on immune system and cytokine expression. Med Microbiol. Immunol. 2017, 206, 1-9. [CrossRef] [PubMed]

53. McDonald, B.; McCoy, K.D. Maternal microbiota in pregnancy and early life. Science 2019, 365, 984-985. [CrossRef] [PubMed]

54. Koletzko, B.; Brands, B.; Grote, V.; Kirchberg, F.F.; Prell, C.; Rzehak, P.; Uhl, O.; Weber, M. Long-Term Health Impact of Early Nutrition: The Power of Programming. Ann. Nutr. Metab. 2017, 70, 161-169. [CrossRef]

55. Hullar, M.A.J.; Fu, B.C. Diet, the Gut Microbiome, and Epigenetics. Cancer J. 2014, 20, 170-175. [CrossRef]

56. Hensch, T.K. Critical period plasticity in local cortical circuits. Nat. Rev. Neurosci. 2005, 6, 877-888. [CrossRef] 
57. Burggren, W.; Mueller, C.A. Developmental Critical Windows and Sensitive Periods as Three-Dimensional Constructs in Time and Space. Physiol. Biochem. Zool. 2015, 88, 91-102. [CrossRef]

58. Robertson, R.C.; Manges, A.R.; Finlay, B.B.; Prendergast, A.J. The Human Microbiome and Child Growth—First 1000 Days and Beyond. Trends Microbiol. 2019, 27, 131-147. [CrossRef]

59. Cowan, C.S.M.; Dinan, T.G.; Cryan, J.F. Annual Research Review: Critical windows-The microbiota-gut-brain axis in neurocognitive development. J. Child Psychol. Psychiatry 2019, 61, 353-371. [CrossRef]

60. Martin, C.R.; Ling, P.-R.; Blackburn, G.L. Review of Infant Feeding: Key Features of Breast Milk and Infant Formula. Nutrients 2016, 8, 279. [CrossRef]

61. Goyal, M.S.; Venkatesh, S.; Milbrandt, J.; Gordon, J.I.; Raichle, M.E. Feeding the brain and nurturing the mind: Linking nutrition and the gut microbiota to brain development. Proc. Natl. Acad. Sci. USA 2015, 112, 14105-14112. [CrossRef] [PubMed]

62. Ismail, F.Y.; Fatemi, A.; Johnston, M.V. Cerebral plasticity: Windows of opportunity in the developing brain. Eur. J. Paediatr. Neurol. 2017, 21, 23-48. [CrossRef] [PubMed]

63. Huus, K.E.; Bauer, K.C.; Brown, E.M.; Bozorgmehr, T.; Woodward, S.E.; Serapio-Palacios, A.; Boutin, R.C.; Petersen, C.; Finlay, B.B. Commensal Bacteria Modulate Immunoglobulin A Binding in Response to Host Nutrition. Cell Host Microbe 2020, 27, 909-921.e905. [CrossRef] [PubMed]

64. Prevention of neural tube defects: Results of the Medical Research Council Vitamin Study. MRC Vitamin Study Research Group. Lancet 1991, 338, 131-137. [CrossRef]

65. Kinoshita, M.; Kayama, H.; Kusu, T.; Yamaguchi, T.; Kunisawa, J.; Kiyono, H.; Sakaguchi, S.; Takeda, K. Dietary Folic Acid Promotes Survival of Foxp3+ Regulatory T Cells in the Colon. J. Immunol. 2012, 189, 2869-2878. [CrossRef]

66. Matok, I.; Gorodischer, R.; Koren, G.; Landau, D.; Wiznitzer, A.; Levy, A. Exposure to folic acid antagonists during the first trimester of pregnancy and the risk of major malformations. Br. J. Clin. Pharmacol. 2009, 68, 956-962. [CrossRef]

67. Shere, M.; Bapat, P.; Nickel, C.; Kapur, B.; Koren, G. Association Between Use of Oral Contraceptives and Folate Status: A Systematic Review and Meta-Analysis. J. Obstet. Gynaecol. Can. 2015, 37, 430-438. [CrossRef]

68. Feinberg, J.I.; Bakulski, K.M.; Jaffe, A.E.; Tryggvadottir, R.; Brown, S.C.; Goldman, L.R.; Croen, L.A.; Hertz-Picciotto, I.; Newschaffer, C.J.; Fallin, M.D.; et al. Paternal sperm DNA methylation associated with early signs of autism risk in an autismenriched cohort. Int. J. Epidemiol. 2015, 44, 1199-1210. [CrossRef]

69. Short, A.K.; Yeshurun, S.; Powell, R.; Perreau, V.M.; Fox, A.; Kim, J.H.; Pang, T.Y.; Hannan, A.J. Exercise alters mouse sperm small noncoding RNAs and induces a transgenerational modification of male offspring conditioned fear and anxiety. Transl. Psychiatry 2017, 7, e1114. [CrossRef]

70. Tyebji, S.; Hannan, A.J.; Tonkin, C.J. Pathogenic Infection in Male Mice Changes Sperm Small RNA Profiles and Transgenerationally Alters Offspring Behavior. Cell Rep. 2020, 31, 107573. [CrossRef]

71. Marques, A.H.; O'Connor, T.G.; Eroth, C.; Susser, E.; Ebjørke-Monsen, A.-L. The influence of maternal prenatal and early childhood nutrition and maternal prenatal stress on offspring immune system development and neurodevelopmental disorders. Front. Neurosci. 2013, 7, 120. [CrossRef] [PubMed]

72. Abrahamsson, T.R.; Wu, R.Y.; Jenmalm, M.C. Gut microbiota and allergy: The importance of the pregnancy period. Pediatr. Res. 2015, 77, 214-219. [CrossRef] [PubMed]

73. Thorburn, A.N.; McKenzie, C.I.; Shen, S.; Stanley, D.; Macia, L.; Mason, L.J.; Roberts, L.K.; Wong, C.H.Y.; Shim, R.; Robert, R.; et al. Evidence that asthma is a developmental origin disease influenced by maternal diet and bacterial metabolites. Nat. Commun. 2015, 6, 7320. [CrossRef] [PubMed]

74. MacPherson, A.J.; De Agüero, M.G.; Ganal-Vonarburg, S.C. How nutrition and the maternal microbiota shape the neonatal immune system. Nat. Rev. Immunol. 2017, 17, 508-517. [CrossRef] [PubMed]

75. Rackaityte, E.; Halkias, J.; Fukui, E.M.; Mendoza, V.F.; Hayzelden, C.; Crawford, E.D.; Fujimura, K.E.; Burt, T.D.; Lynch, S.V. Viable bacterial colonization is highly limited in the human intestine in utero. Nat. Med. 2020, 26, 599-607. [CrossRef]

76. Stiles, J.; Jernigan, T.L. The Basics of Brain Development. Neuropsychol. Rev. 2010, 20, 327-348. [CrossRef]

77. Knickmeyer, R.C.; Gouttard, S.; Kang, C.; Evans, D.; Wilber, K.; Smith, J.K.; Hamer, R.M.; Lin, W.; Gerig, G.; Gilmore, J.H. A Structural MRI Study of Human Brain Development from Birth to 2 Years. J. Neurosci. 2008, 28, 12176-12182. [CrossRef]

78. Tau, G.Z.; Peterson, B.S. Normal Development of Brain Circuits. Neuropsychopharmacology 2009, 35, 147-168. [CrossRef]

79. Knudsen, E.I. Sensitive Periods in the Development of the Brain and Behavior. J. Cogn. Neurosci. 2004, 16, 1412-1425. [CrossRef]

80. Brunton, P.J. Effects of maternal exposure to social stress during pregnancy: Consequences for mother and offspring. Reproduction 2013, 146, R175-R189. [CrossRef]

81. Chu, D.M.; Antony, K.M.; Ma, J.; Prince, A.L.; Showalter, L.; Moller, M.; Aagaard, K.M. The early infant gut microbiome varies in association with a maternal high-fat diet. Genome Med. 2016, 8, 77. [CrossRef] [PubMed]

82. Gómez-Pinilla, F. Brain foods: The effects of nutrients on brain function. Nat. Rev. Neurosci. 2008, 9, 568-578. [CrossRef] [PubMed]

83. Spencer, S.J.; Korosi, A.; Layé, S.; Shukitt-Hale, B.; Barrientos, R.M. Food for thought: How nutrition impacts cognition and emotion. npj Sci. Food 2017, 1. [CrossRef] [PubMed]

84. Institute of Medicine Committee on Military Nutrition. Food Components to Enhance Performance: An Evaluation of Potential Performance-Enhancing Food Components for Operational Rations; Marriott, B.M., Ed.; National Academies Press: Washington, DC, USA, 1940. [CrossRef] 
85. Tran, T.D.; Biggs, B.-A.; Tran, T.; Simpson, J.A.; Hanieh, S.; Dwyer, T.; Fisher, J. Impact on Infants' Cognitive Development of Antenatal Exposure to Iron Deficiency Disorder and Common Mental Disorders. PLoS ONE 2013, 8, e74876. [CrossRef]

86. Cusick, S.E.; Georgieff, M.K. The Role of Nutrition in Brain Development: The Golden Opportunity of the "First 1000 Days". J. Pediatr. 2016, 175, 16-21. [CrossRef]

87. Ars, C.L.; Nijs, I.M.; Marroun, H.E.; Muetzel, R.; Schmidt, M.; Graaff, J.S.-D.; Van Der Lugt, A.; Jaddoe, V.W.; Hofman, A.; Steegers, E.A.; et al. Prenatal folate, homocysteine and vitamin B12 levels and child brain volumes, cognitive development and psychological functioning: The Generation R Study. Br. J. Nutr. 2016, 122, S1-S9. [CrossRef]

88. Craig, S.A. Betaine in human nutrition. Am. J. Clin. Nutr. 2004, 80, 539-549. [CrossRef]

89. García-Mantrana, I.; Selma-Royo, M.; González, S.; Parra-Llorca, A.; Martínez-Costa, C.; Collado, M. Distinct maternal microbiota clusters are associated with diet during pregnancy: Impact on neonatal microbiota and infant growth during the first 18 months of life. Gut Microbes 2020, 11, 962-978. [CrossRef]

90. Kimura, I.; Miyamoto, J.; Ohue-Kitano, R.; Watanabe, K.; Yamada, T.; Onuki, M.; Aoki, R.; Isobe, Y.; Kashihara, D.; Inoue, D.; et al. Maternal gut microbiota in pregnancy influences offspring metabolic phenotype in mice. Science 2020, 367, eaaw8429. [CrossRef]

91. Arroyo-Johnson, C.; Mincey, K.D. Obesity Epidemiology Worldwide. Gastroenterol. Clin. N. Am. 2016, 45, 571-579. [CrossRef]

92. Collado, M.; Isolauri, E.; Laitinen, K.; Salminen, S. Effect of mother's weight on infant's microbiota acquisition, composition, and activity during early infancy: A prospective follow-up study initiated in early pregnancy. Am. J. Clin. Nutr. 2010, 92, 1023-1030. [CrossRef] [PubMed]

93. Mueller, N.T.; Shin, H.; Pizoni, A.; Werlang, I.C.; Matte, U.; Goldani, M.Z.; Goldani, H.A.S.; Dominguez-Bello, M.G. Birth mode-dependent association between pre-pregnancy maternal weight status and the neonatal intestinal microbiome. Sci. Rep. 2016, 6, 23133. [CrossRef] [PubMed]

94. Wexler, H.M.; Daya, S.; Berns, K.I. Bacteroides: The Good, the Bad, and the Nitty-Gritty. Clin. Microbiol. Rev. 2007, $20,593-621$. [CrossRef] [PubMed]

95. Al Rubaye, H.; Adamson, C.C.; Jadavji, N.M. The role of maternal diet on offspring gut microbiota development: A review. J. Neurosci. Res. 2021, 99, 284-293. [CrossRef] [PubMed]

96. Buffington, S.A.; Di Prisco, G.V.; Auchtung, T.A.; Ajami, N.J.; Petrosino, J.F.; Costa-Mattioli, M. Microbial Reconstitution Reverses Maternal Diet-Induced Social and Synaptic Deficits in Offspring. Cell 2016, 165, 1762-1775. [CrossRef] [PubMed]

97. Hallam, M.C.; Barile, D.; Meyrand, M.; German, J.B.; Reimer, R.A. Maternal high-protein or high-prebiotic-fiber diets affect maternal milk composition and gut microbiota in rat dams and their offspring. Obesity 2014, 22, 2344-2351. [CrossRef]

98. Koren, O.; Goodrich, J.K.; Cullender, T.C.; Spor, A.; Laitinen, K.; Bäckhed, H.K.; Gonzalez, A.; Werner, J.J.; Angenent, L.T.; Knight, R.; et al. Host Remodeling of the Gut Microbiome and Metabolic Changes during Pregnancy. Cell 2012, 150, 470-480. [CrossRef]

99. Popkov, V.A.; Silachev, D.N.; Jankauskas, S.S.; Zorova, L.D.; Pevzner, I.B.; Babenko, V.A.; Plotnikov, E.Y.; Zorov, D.B. Molecular and cellular interactions between mother and fetus. Pregnancy as a rejuvenating factor. Biochemistry 2016, 81, 1480-1487. [CrossRef]

100. Jašarević, E.; Bale, T.L. Prenatal and postnatal contributions of the maternal microbiome on offspring programming. Front. Neuroendocr. 2019, 55, 100797. [CrossRef]

101. Perez-Muñoz, M.E.; Arrieta, M.-C.; Ramer-Tait, A.E.; Walter, J. A critical assessment of the "sterile womb" and "in utero colonization" hypotheses: Implications for research on the pioneer infant microbiome. Microbiome 2017, 5, 48. [CrossRef]

102. Stinson, L.F.; Boyce, M.C.; Payne, M.S.; Keelan, J.A. The Not-so-Sterile Womb: Evidence That the Human Fetus Is Exposed to Bacteria Prior to Birth. Front. Microbiol. 2019, 10, 1124. [CrossRef] [PubMed]

103. De Goffau, M.C.; Charnock-Jones, D.S.; Smith, G.C.S.; Parkhill, J. Batch effects account for the main findings of an in utero human intestinal bacterial colonization study. Microbiome 2021, 9, 1-7. [CrossRef] [PubMed]

104. Walter, J.; Hornef, M.W. A philosophical perspective on the prenatal in utero microbiome debate. Microbiome 2021, 9, 1-9. [CrossRef] [PubMed]

105. Rautava, S.; Collado, M.C.; Salminen, S.; Isolauri, E. Probiotics Modulate Host-Microbe Interaction in the Placenta and Fetal Gut: A Randomized, Double-Blind, Placebo-Controlled Trial. Neonatology 2012, 102, 178-184. [CrossRef] [PubMed]

106. Vuong, H.E.; Pronovost, G.N.; Williams, D.W.; Coley, E.J.L.; Siegler, E.L.; Qiu, A.; Kazantsev, M.; Wilson, C.J.; Rendon, T.; Hsiao, E.Y. The maternal microbiome modulates fetal neurodevelopment in mice. Nat. Cell Biol. 2020, 586, 281-286. [CrossRef]

107. Jašarević, E.; Howard, C.D.; Morrison, K.E.; Misic, A.; Weinkopff, T.; Scott, P.; Hunter, C.; Beiting, D.; Bale, T.L. The maternal vaginal microbiome partially mediates the effects of prenatal stress on offspring gut and hypothalamus. Nat. Neurosci. 2018, 21, 1061-1071. [CrossRef]

108. Knuesel, I.; Chicha, L.; Britschgi, M.; Schobel, S.A.; Bodmer, M.; Hellings, J.A.; Toovey, S.; Prinssen, E.P. Maternal immune activation and abnormal brain development across CNS disorders. Nat. Rev. Neurol. 2014, 10, 643-660. [CrossRef]

109. Girchenko, P.; Lahti-Pulkkinen, M.; Heinonen, K.; Reynolds, R.M.; Laivuori, H.; Lipsanen, J.; Villa, P.M.; Hämäläinen, E.; Kajantie, E.; Lahti, J.; et al. Persistently High Levels of Maternal Antenatal Inflammation Are Associated With and Mediate the Effect of Prenatal Environmental Adversities on Neurodevelopmental Delay in the Offspring. Biol. Psychiatry 2020, 87, 898-907. [CrossRef]

110. Staude, B.; Oehmke, F.; Lauer, T.; Behnke, J.; Göpel, W.; Schloter, M.; Schulz, H.; Krauss-Etschmann, S.; Ehrhardt, H. The Microbiome and Preterm Birth: A Change in Paradigm with Profound Implications for Pathophysiologic Concepts and Novel Therapeutic Strategies. BioMed Res. Int. 2018, 2018, 1-12. [CrossRef]

111. Ream, M.A.; Lehwald, L. Neurologic Consequences of Preterm Birth. Curr. Neurol. Neurosci. Rep. 2018, 18, 48. [CrossRef] 
112. Shao, Y.; Forster, S.C.; Tsaliki, E.; Vervier, K.; Strang, A.; Simpson, N.; Kumar, N.; Stares, M.D.; Rodger, A.; Brocklehurst, P.; et al. Stunted microbiota and opportunistic pathogen colonization in caesarean-section birth. Nat. Cell Biol. 2019, 574, 117-121. [CrossRef] [PubMed]

113. Wang, S.; Ryan, C.A.; Boyaval, P.; Dempsey, E.M.; Ross, R.P.; Stanton, C. Maternal Vertical Transmission Affecting Early-life Microbiota Development. Trends Microbiol. 2020, 28, 28-45. [CrossRef] [PubMed]

114. Jakobsson, H.E.; Abrahamsson, T.R.; Jenmalm, M.C.; Harris, K.; Quince, C.; Jernberg, C.; Björkstén, B.; Engstrand, L.; Andersson, A.F.; Filion, K.B.; et al. Decreased gut microbiota diversity, delayed Bacteroidetes colonisation and reduced Th1 responses in infants delivered by Caesarean section. Gut 2014, 63, 559-566. [CrossRef] [PubMed]

115. Biasucci, G.; Rubini, M.; Riboni, S.; Morelli, L.; Bessi, E.; Retetangos, C. Mode of delivery affects the bacterial community in the newborn gut. Early Hum. Dev. 2010, 86 (Suppl. 1), 13-15. [CrossRef]

116. Azad, M.B.; Konya, T.; Maughan, H.; Guttman, D.S.; Field, C.J.; Chari, R.S.; Sears, M.R.; Becker, A.B.; Scott, J.A.; Kozyrskyj, A.L.; et al. Gut microbiota of healthy Canadian infants: Profiles by mode of delivery and infant diet at 4 months. Can. Med Assoc. J. 2013, 185, 385-394. [CrossRef]

117. Hill, C.J.; Lynch, D.B.; Murphy, K.; Ulaszewska, M.; Jeffery, I.B.; O’Shea, C.A.; Watkins, C.; Dempsey, E.; Mattivi, F.; Tuohy, K.; et al. Evolution of gut microbiota composition from birth to 24 weeks in the INFANTMET Cohort. Microbiome 2017, 5, 1-18. [CrossRef]

118. Fouhy, F.; Watkins, C.; Hill, C.J.; O'Shea, C.-A.; Nagle, B.; Dempsey, E.M.; O’Toole, P.W.; Ross, R.P.; Ryan, C.A.; Stanton, C. Perinatal factors affect the gut microbiota up to four years after birth. Nat. Commun. 2019, 10, 1517. [CrossRef]

119. Chu, D.M.; Ma, J.; Prince, A.L.; Antony, K.M.; Seferovic, M.D.; Aagaard, K.M. Maturation of the infant microbiome community structure and function across multiple body sites and in relation to mode of delivery. Nat. Med. 2017, 23, 314-326. [CrossRef]

120. Cabrera-Rubio, R.; Collado, M.C.; Laitinen, K.; Salminen, S.; Isolauri, E.; Miras, A.D.; Jackson, R.N.; Jackson, S.N.; Goldstone, A.P.; Olbers, T.; et al. The human milk microbiome changes over lactation and is shaped by maternal weight and mode of delivery. Am. J. Clin. Nutr. 2012, 96, 544-551. [CrossRef]

121. Hermansson, H.; Kumar, H.; Collado, M.C.; Salminen, S.; Isolauri, E.; Rautava, S. Breast Milk Microbiota Is Shaped by Mode of Delivery and Intrapartum Antibiotic Exposure. Front. Nutr. 2019, 6, 4. [CrossRef]

122. Vindigni, S.M.; Surawicz, C.M. Fecal Microbiota Transplantation. Gastroenterol. Clin. N. Am. 2017, 46, 171-185. [CrossRef] [PubMed]

123. Hourigan, S.K.; Oliva-Hemker, M. Fecal microbiota transplantation in children: A brief review. Pediatr. Res. 2016, 80, 2-6. [CrossRef]

124. Korpela, K.; Helve, O.; Kolho, K.-L.; Saisto, T.; Skogberg, K.; Dikareva, E.; Stefanovic, V.; Salonen, A.; Andersson, S.; De Vos, W.M. Maternal Fecal Microbiota Transplantation in Cesarean-Born Infants Rapidly Restores Normal Gut Microbial Development: A Proof-of-Concept Study. Cell 2020, 183, 324-334.e325. [CrossRef] [PubMed]

125. McCann, A.; Ryan, F.J.; Stockdale, S.R.; Dalmasso, M.; Blake, T.; Ryan, C.A.; Stanton, C.; Mills, S.; Ross, P.R.; Hill, C. Viromes of one year old infants reveal the impact of birth mode on microbiome diversity. Peer] 2018, 6, e4694. [CrossRef] [PubMed]

126. Maqsood, R.; Rodgers, R.; Rodriguez, C.; Handley, S.A.; Ndao, I.M.; Tarr, P.I.; Warner, B.B.; Lim, E.S.; Holtz, L.R. Discordant transmission of bacteria and viruses from mothers to babies at birth. Microbiome 2019, 7, 156. [CrossRef] [PubMed]

127. Roduit, C.; Scholtens, S.; De Jongste, J.C.; Wijga, A.H.; Gerritsen, J.; Postma, D.S.; Brunekreef, B.; Hoekstra, M.O.; Aalberse, R.; Smit, H.A. Asthma at 8 years of age in children born by caesarean section. Thorax 2009, 64, 107-113. [CrossRef] [PubMed]

128. Bisgaard, H.; Li, N.; Bonnelykke, K.; Chawes, B.L.K.; Skov, T.; Paludan-Müller, G.; Stokholm, J.; Smith, B.; Krogfelt, K.A. Reduced diversity of the intestinal microbiota during infancy is associated with increased risk of allergic disease at school age. J. Allergy Clin. Immunol. 2011, 128, 646-652.e5. [CrossRef]

129. Stokholm, J.; Thorsen, J.; Blaser, M.J.; Rasmussen, M.A.; Hjelmsø, M.; Shah, S.A.; Christensen, E.D.; Chawes, B.L.; Bønnelykke, K.; Brix, S.; et al. Delivery mode and gut microbial changes correlate with an increased risk of childhood asthma. Sci. Transl. Med. 2020, 12, eaax9929. [CrossRef]

130. Blustein, J.; Attina, T.M.; Liu, M.; Ryan, A.M.; Cox, L.M.; Blaser, M.J.; Trasande, L. Association of caesarean delivery with child adiposity from age 6 weeks to 15 years. Int. J. Obes. 2013, 37, 900-906. [CrossRef]

131. Montoya-Williams, D.; Lemas, D.J.; Spiryda, L.; Patel, K.; Carney, O.O.; Neu, J.; Carson, T.L. The Neonatal Microbiome and Its Partial Role in Mediating the Association between Birth by Cesarean Section and Adverse Pediatric Outcomes. Neonatology 2018, 114, 103-111. [CrossRef]

132. Al Khalaf, S.Y.; O’Neill, S.M.; O’Keeffe, L.M.; Henriksen, T.B.; Kenny, L.C.; Cryan, J.F.; Khashan, A.S. The impact of obstetric mode of delivery on childhood behavior. Soc. Psychiatry Psychiatr. Epidemiol. 2015, 50, 1557-1567. [CrossRef] [PubMed]

133. Curran, E.A.; Kenny, L.C.; Dalman, C.; Kearney, P.M.; Cryan, J.F.; Dinan, T.G.; Khashan, A.S. Birth by caesarean section and school performance in Swedish adolescents- a population-based study. BMC Pregnancy Childbirth 2017, 17, 121. [CrossRef] [PubMed]

134. Slykerman, R.F.; Li, E.; Milne, B.J. Birth by caesarean section and educational achievement in adolescents. Aust. N. Z. J. Obstet. Gynaecol. 2020. [CrossRef] [PubMed]

135. Hanrahan, M.; McCarthy, F.P.; O'Keeffe, G.W.; Khashan, A.S. The association between caesarean section and cognitive ability in childhood. Soc. Psychiatry Psychiatr. Epidemiol. 2020, 55, 1231-1240. [CrossRef] [PubMed]

136. Castillo-Ruiz, A.; Mosley, M.; Jacobs, A.J.; Hoffiz, Y.C.; Forger, N.G. Birth delivery mode alters perinatal cell death in the mouse brain. Proc. Natl. Acad. Sci. USA 2018, 115, 11826-11831. [CrossRef] [PubMed] 
137. Chiesa, M.; Guimond, D.; Tyzio, R.; Pons-Bennaceur, A.; Lozovaya, N.; Burnashev, N.; Ferrari, D.C.; Ben-Ari, Y. Term or Preterm Cesarean Section Delivery Does Not Lead to Long-term Detrimental Consequences in Mice. Cereb. Cortex 2019, 29, $2424-2436$. [CrossRef]

138. Morais, L.H.; Golubeva, A.V.; Moloney, G.M.; Moya-Pérez, A.; Ventura-Silva, A.P.; Arboleya, S.; Bastiaanssen, T.F.; O'Sullivan, O.; Rea, K.; Borre, Y.; et al. Enduring Behavioral Effects Induced by Birth by Caesarean Section in the Mouse. Curr. Biol. 2020, 30, 3761-3774.e3766. [CrossRef]

139. Patel, R.M.; Myers, L.S.; Kurundkar, A.R.; Maheshwari, A.; Nusrat, A.; Denning, P.W. Probiotic Bacteria Induce Maturation of Intestinal Claudin 3 Expression and Barrier Function. Am. J. Pathol. 2012, 180, 626-635. [CrossRef]

140. Bergmann, K.R.; Liu, S.X.; Tian, R.; Kushnir, A.; Turner, J.R.; Li, H.-L.; Chou, P.M.; Weber, C.R.; De Plaen, I.G. Bifidobacteria Stabilize Claudins at Tight Junctions and Prevent Intestinal Barrier Dysfunction in Mouse Necrotizing Enterocolitis. Am. J. Pathol. 2013, 182, 1595-1606. [CrossRef]

141. Luck, B.; Engevik, M.A.; Ganesh, B.P.; Lackey, E.P.; Lin, T.; Balderas, M.; Major, A.; Runge, J.; Luna, R.A.; Sillitoe, R.V.; et al. Bifidobacteria shape host neural circuits during postnatal development by promoting synapse formation and microglial function. Sci. Rep. 2020, 10, 7737. [CrossRef]

142. Desbonnet, L.; Garrett, L.; Clarke, G.; Kiely, B.; Cryan, J.F.; Dinan, T.G. Effects of the probiotic Bifidobacterium infantis in the maternal separation model of depression. Neuroscience 2010, 170, 1179-1188. [CrossRef] [PubMed]

143. O'Callaghan, A.; Van Sinderen, D. Bifidobacteria and Their Role as Members of the Human Gut Microbiota. Front. Microbiol. 2016, 7, 925. [CrossRef] [PubMed]

144. Beidelman, A.I.; Schanler, R.J. Breastfeeding and the Use of Human Milk. Pediatrics 2012, 129, e827-e841. [CrossRef]

145. Valentine, C.J.; Wagner, C.L. Nutritional Management of the Breastfeeding Dyad. Pediatr. Clin. N. Am. 2013, 60, 261-274. [CrossRef]

146. Victora, C.G.; Bahl, R.; Barros, A.J.D.; França, G.V.; Horton, S.; Krasevec, J.; Murch, S.; Sankar, M.J.; Walker, N.; Rollins, N.C.; et al. Breastfeeding in the 21st century: Epidemiology, mechanisms, and lifelong effect. Lancet 2016, 387, 475-490. [CrossRef]

147. Ballard, O.; Morrow, A.L. Human Milk Composition. Pediatr. Clin. N. Am. 2013, 60, 49-74. [CrossRef]

148. Neville, M.C.; Anderson, S.M.; McManaman, J.L.; Badger, T.M.; Bunik, M.; Contractor, N.; Crume, T.; Dabelea, D.; Donovan, S.M.; Forman, N.; et al. Lactation and Neonatal Nutrition: Defining and Refining the Critical Questions. J. Mammary Gland. Biol. Neoplasia 2012, 17, 167-188. [CrossRef]

149. Kramer, M.S.; Kakuma, R. Optimal duration of exclusive breastfeeding. Cochrane Database Syst. Rev. 2012, 2012, CD003517. [CrossRef]

150. Kominiarek, M.A.; Rajan, P. Nutrition Recommendations in Pregnancy and Lactation. Med Clin. N. Am. 2016, 100, 1199-1215. [CrossRef]

151. Di Benedetto, M.G.; Bottanelli, C.; Cattaneo, A.; Pariante, C.M.; Borsini, A. Nutritional and immunological factors in breast milk: A role in the intergenerational transmission from maternal psychopathology to child development. Brain Behav. Immun. 2020, 85, 57-68. [CrossRef]

152. Emmett, P.M.; Rogers, I.S. Properties of human milk and their relationship with maternal nutrition. Early Hum. Dev. 1997, 49, S7-S28. [CrossRef]

153. Butte, N.F.; King, J.C. Energy requirements during pregnancy and lactation. Public Heal. Nutr. 2005, 8, 1010-1027. [CrossRef]

154. Nommsen, L.A.; Lovelady, C.A.; Heinig, M.J.; Lönnerdal, B.; Dewey, K.G. Determinants of energy, protein, lipid, and lactose concentrations in human milk during the first 12 mo of lactation: The DARLING Study. Am. J. Clin. Nutr. 1991, 53, 457-465. [CrossRef]

155. Horta, B.L.; De Sousa, B.A.; De Mola, C.L. Breastfeeding and neurodevelopmental outcomes. Curr. Opin. Clin. Nutr. Metab. Care 2018, 21, 174-178. [CrossRef] [PubMed]

156. Evans, J.; Heron, J.; Francomb, H.; Oke, S.; Golding, J. Cohort study of depressed mood during pregnancy and after childbirth. BMJ 2001, 323, 257-260. [CrossRef] [PubMed]

157. Hibbeln, J.R. Seafood consumption, the DHA content of mothers' milk and prevalence rates of postpartum depression: A crossnational, ecological analysis. J. Affect. Disord. 2002, 69, 15-29. [CrossRef]

158. Keim, S.A.; Daniels, J.L.; Siega-Riz, A.M.; Dole, N.; Herring, A.H.; Scheidt, P.C. Depressive Symptoms during Pregnancy and the Concentration of Fatty Acids in Breast Milk. J. Hum. Lact. 2012, 28, 189-195. [CrossRef]

159. Thibeau, S.; D’Apolito, K.; Minnick, A.F.; Dietrich, M.S.; Kane, B.; Cooley, S.; Groer, M. Relationships of Maternal Stress with Milk Immune Components in African American Mothers of Healthy Term Infants. Breastfeed. Med. 2016, 11, 6-14. [CrossRef]

160. Garofalo, R.P. Cytokines in Human Milk. J. Pediatr. 2010, 156, S36-S40. [CrossRef]

161. Dewey, K.G.; Heinig, M.J.; A Nommsen, L.; Lonnerdal, B. Maternal versus infant factors related to breast milk intake and residual milk volume: The DARLING study. Pediatrics 1991, 87, 829-837.

162. Picciano, M.F. Pregnancy and Lactation: Physiological Adjustments, Nutritional Requirements and the Role of Dietary Supplements. J. Nutr. 2003, 133, 1997S-2002S. [CrossRef] [PubMed]

163. Underwood, M.A. Human Milk for the Premature Infant. Pediatr. Clin. N. Am. 2013, 60, 189-207. [CrossRef] [PubMed]

164. Al Nabhani, Z.; Dulauroy, S.; Marques, R.; Cousu, C.; Al Bounny, S.; Déjardin, F.; Sparwasser, T.; Bérard, M.; Cerf-Bensussan, N.; Eberl, G. A Weaning Reaction to Microbiota Is Required for Resistance to Immunopathologies in the Adult. Immunity 2019, 50, 1276-1288.e1275. [CrossRef] [PubMed] 
165. Brink, L.R.; Lönnerdal, B. Milk fat globule membrane: The role of its various components in infant health and development. J. Nutr. Biochem. 2020, 85, 108465. [CrossRef] [PubMed]

166. Lönnerdal, B. Nutritional and physiologic significance of human milk proteins. Am. J. Clin. Nutr. 2003, 77, 1537S-1543S. [CrossRef]

167. Jackson, J.G.; Janszen, D.B.; Lonnerdal, B.; Lien, E.L.; Pramuk, K.P.; Kuhlman, C.F. A multinational study of $\alpha$-lactalbumin concentrations in human milk. J. Nutr. Biochem. 2004, 15, 517-521. [CrossRef] [PubMed]

168. Villavicencio, A.; Rueda, M.S.; Turin, C.G.; Ochoa, T.J. Factors affecting lactoferrin concentration in human milk: How much do we know? Biochem. Cell Biol. 2017, 95, 12-21. [CrossRef] [PubMed]

169. Agarwal, S.; Karmaus, W.; Davis, S.R.; Gangur, V. Review: Immune Markers in Breast Milk and Fetal and Maternal Body Fluids: A Systematic Review of Perinatal Concentrations. J. Hum. Lact. 2011, 27, 171-186. [CrossRef]

170. Siziba, L.P.; Lorenz, L.; Stahl, B.; Mank, M.; Marosvölgyi, T.; Décsi, T.; Rothenbacher, D.; Genuneit, J. Mank Changes in Human Milk Fatty Acid Composition during Lactation: The Ulm SPATZ Health Study. Nutrients 2019, 11, 2842. [CrossRef]

171. Timby, N.; Domellöf, E.; Hernell, O.; Lönnerdal, B.; Domellöf, M. Neurodevelopment, nutrition, and growth until 12 mo of age in infants fed a low-energy, low-protein formula supplemented with bovine milk fat globule membranes: A randomized controlled trial. Am. J. Clin. Nutr. 2014, 99, 860-868. [CrossRef]

172. Hernell, O.; Timby, N.; Domellöf, M.; Lönnerdal, B. Clinical Benefits of Milk Fat Globule Membranes for Infants and Children. J. Pediatr. 2016, 173, S60-S65. [CrossRef] [PubMed]

173. Wang, L.; Zhu, F.; Yang, H.; Li, J.; Li, Y.; Ding, X.; Xiong, X.; Yin, Y. Effects of dietary supplementation with epidermal growth factor on nutrient digestibility, intestinal development and expression of nutrient transporters in early-weaned piglets. J. Anim. Physiol. Anim. Nutr. 2019, 103, 618-625. [CrossRef]

174. Khailova, L.; Dvorak, K.; Arganbright, K.M.; Williams, C.S.; Halpern, M.D.; Dvorak, B. Changes in Hepatic Cell Junctions Structure During Experimental Necrotizing Enterocolitis: Effect of EGF Treatment. Pediatr. Res. 2009, 66, 140-144. [CrossRef] [PubMed]

175. Fichter, M.; Klotz, M.; Hirschberg, D.L.; Waldura, B.; Schofer, O.; Ehnert, S.; Schwarz, L.K.; Van Ginneken, C.; Schäfer, K.-H. Breast milk contains relevant neurotrophic factors and cytokines for enteric nervous system development. Mol. Nutr. Food Res. 2011, 55, 1592-1596. [CrossRef]

176. Boesmans, W.; Gomes, P.; Janssens, J.; Tack, J.; Berghe, P.V. Brain-derived neurotrophic factor amplifies neurotransmitter responses and promotes synaptic communication in the enteric nervous system. Gut 2008, 57, 314-322. [CrossRef] [PubMed]

177. Shiou, S.-R.; Yu, Y.; Chen, S.; Ciancio, M.J.; Petrof, E.O.; Sun, J.; Claud, E.C. Erythropoietin Protects Intestinal Epithelial Barrier Function and Lowers the Incidence of Experimental Neonatal Necrotizing Enterocolitis. J. Biol. Chem. 2011, 286, 12123-12132. [CrossRef] [PubMed]

178. Newburg, D.S.; Woo, J.G.; Morrow, A.L. Characteristics and Potential Functions of Human Milk Adiponectin. J. Pediatr. 2010, 156, S41-S46. [CrossRef] [PubMed]

179. Woo, J.G.; Guerrero, M.L.; Guo, F.; Martin, L.J.; Davidson, B.S.; Ortega, H.; Ruiz-Palacios, G.M.; Morrow, A.L. Human Milk Adiponectin Affects Infant Weight Trajectory During the Second Year of Life. J. Pediatr. Gastroenterol. Nutr. 2012, 54, 532-539. [CrossRef] [PubMed]

180. Dündar, N.O.; Dundar, B.; Cesur, G.; Yılmaz, N.; Sutcu, R.; Ozguner, F.; Yilmaz, N. Ghrelin and adiponectin levels in colostrum, cord blood and maternal serum. Pediatr. Int. 2010, 52, 622-625. [CrossRef]

181. Yatsunenko, T.; Rey, F.E.; Manary, M.J.; Trehan, I.; Dominguez-Bello, M.G.; Contreras, M.; Magris, M.; Hidalgo, G.; Baldassano, R.N.; Anokhin, A.P.; et al. Human gut microbiome viewed across age and geography. Nature 2012, 486, 222-227. [CrossRef]

182. Gordon, I.; Zagoory-Sharon, O.; Leckman, J.F.; Feldman, R. Oxytocin, cortisol, and triadic family interactions. Physiol. Behav. 2010, 101, 679-684. [CrossRef] [PubMed]

183. Steinbach, X.; Maasen, S. Oxytocin: From a Hormone for Birth to a Social Hormone: The Hormonal Governance of Sociability aka Society. Ntm 2018, 26, 1-30. [CrossRef] [PubMed]

184. Gura, T. Nature's first functional food. Science 2014, 345, 747-749. [CrossRef] [PubMed]

185. Akbari, P.; Fink-Gremmels, J.; Willems, R.H.A.M.; DiFilippo, E.; Schols, H.A.; Schoterman, M.H.C.; Garssen, J.; Braber, S. Characterizing microbiota-independent effects of oligosaccharides on intestinal epithelial cells: Insight into the role of structure and size: Structure-activity relationships of non-digestible oligosaccharides. Eur. J. Nutr. 2017, 56, 1919-1930. [CrossRef]

186. Lemaire, M.; Le Huërou-Luron, I.; Blat, S. Effects of infant formula composition on long-term metabolic health. J. Dev. Orig. Heal. Dis. 2018, 9, 573-589. [CrossRef]

187. Berger, P.K.; Plows, J.F.; Jones, R.B.; Alderete, T.L.; Yonemitsu, C.; Poulsen, M.; Ryoo, J.H.; Peterson, B.S.; Bode, L.; Goran, M.I. Human milk oligosaccharide 2 '-fucosyllactose links feedings at 1 month to cognitive development at 24 months in infants of normal and overweight mothers. PLoS ONE 2020, 15, e0228323. [CrossRef]

188. Somasundaram, I.; Dhanasekaran, M.; Rajkumar, J.S.; Sudarsanam, D. Exploring the stem cell and non-stem cell constituents of human breast milk. Cytotechnology 2012, 65, 385-393. [CrossRef]

189. Lee, H.; Padhi, E.; Hasegawa, Y.; Larke, J.; Parenti, M.; Wang, A.; Hernell, O.; Lönnerdal, B.; Slupsky, C.M. Compositional Dynamics of the Milk Fat Globule and Its Role in Infant Development. Front. Pediatr. 2018, 6, 313. [CrossRef] 
190. Peterson, J.A.; Hamosh, M.; Scallan, C.D.; Ceriani, R.L.; Henderson, T.R.; Mehta, N.R.; Armand, M.; Hamosh, P. Milk Fat Globule Glycoproteins in Human Milk and in Gastric Aspirates of Mother's Milk-Fed Preterm Infants. Pediatr. Res. 1998, 44, 499-506. [CrossRef]

191. Pacheco, A.R.; Barile, D.; Underwood, M.A.; Mills, D.A. The impact of the milk glycobiome on the neonate gut microbiota. Annu. Rev. Anim. Biosci. 2015, 3, 419-445. [CrossRef]

192. Vickers, M.H.; Guan, J.; Gustavsson, M.; Bharatharaj, J.; Breier, B.H.; Davison, M.; Fong, B.; Norris, C.; McJarrow, P.; Hodgkinson, S.C. Supplementation with a mixture of complex lipids derived from milk to growing rats results in improvements in parameters related to growth and cognition. Nutr. Res. 2009, 29, 426-435. [CrossRef] [PubMed]

193. Mahony, S.M.O.; Neufeld, K.M.; Waworuntu, R.V.; Pusceddu, M.M.; Manurung, S.; Murphy, K.; Strain, C.; Laguna, M.C.; Peterson, V.L.; Stanton, C.; et al. The enduring effects of early-life stress on the microbiota-gut-brain axis are buffered by dietary supplementation with milk fat globule membrane and a prebiotic blend. Eur. J. Neurosci. 2020, 51, 1042-1058. [CrossRef]

194. Nishimaru, H.; Restrepo, C.E.; Ryge, J.; Yanagawa, Y.; Kiehn, O. Mammalian motor neurons corelease glutamate and acetylcholine at central synapses. Proc. Natl. Acad. Sci. USA 2005, 102, 5245-5249. [CrossRef] [PubMed]

195. Hasselmo, M.E. The role of acetylcholine in learning and memory. Curr. Opin. Neurobiol. 2006, 16, 710-715. [CrossRef] [PubMed]

196. Schverer, M.; O’Mahony, S.M.; O’Riordan, K.J.; Donoso, F.; Roy, B.L.; Stanton, C.; Dinan, T.G.; Schellekens, H.; Cryan, J.F. Dietary phospholipids: Role in cognitive processes across the lifespan. Neurosci. Biobehav. Rev. 2020, 111, 183-193. [CrossRef]

197. Tanaka, K.; Hosozawa, M.; Kudo, N.; Yoshikawa, N.; Hisata, K.; Shoji, H.; Shinohara, K.; Shimizu, T. The pilot study: Sphingomyelin-fortified milk has a positive association with the neurobehavioural development of very low birth weight infants during infancy, randomized control trial. Brain Dev. 2013, 35, 45-52. [CrossRef] [PubMed]

198. McGuire, M.K.; Meehan, C.L.; McGuire, M.A.; Williams, J.E.; Foster, J.; Sellen, D.W.; Kamau-Mbuthia, E.W.; Kamundia, E.W.; Mbugua, S.; Moore, S.E.; et al. What's normal? Oligosaccharide concentrations and profiles in milk produced by healthy women vary geographically. Am. J. Clin. Nutr. 2017, 105, 1086-1100. [CrossRef]

199. Smilowitz, J.T.; O'Sullivan, A.; Barile, D.; German, J.B.; Lönnerdal, B.; Slupsky, C.M. The Human Milk Metabolome Reveals Diverse Oligosaccharide Profiles. J. Nutr. 2013, 143, 1709-1718. [CrossRef]

200. Seferovic, M.D.; Mohammad, M.; Pace, R.M.; Engevik, M.; Versalovic, J.; Bode, L.; Haymond, M.; Aagaard, K.M. Maternal diet alters human milk oligosaccharide composition with implications for the milk metagenome. Sci. Rep. 2020, 10, 22092. [CrossRef]

201. Stuebe, A.; Seed, P.C.; LaTuga, M. A Review of the Source and Function of Microbiota in Breast Milk. Semin. Reprod. Med. 2014, 32, 068-073. [CrossRef]

202. Jost, T.; Lacroix, C.; Braegger, C.P.; Chassard, C. Impact of human milk bacteria and oligosaccharides on neonatal gut microbiota establishment and gut health. Nutr. Rev. 2015, 73, 426-437. [CrossRef] [PubMed]

203. Yu, Z.-T.; Chen, C.; Newburg, D.S. Utilization of major fucosylated and sialylated human milk oligosaccharides by isolated human gut microbes. Glycobiology 2013, 23, 1281-1292. [CrossRef] [PubMed]

204. Aakko, J.; Kumar, H.; Rautava, S.; Wise, A.; Autran, C.; Bode, L.; Isolauri, E.; Salminen, S. Human milk oligosaccharide categories define the microbiota composition in human colostrum. Benef. Microbes 2017, 8, 563-567. [CrossRef] [PubMed]

205. Albrecht, S.; Schols, H.A.; Van Zoeren, D.; Van Lingen, R.A.; Jebbink, L.J.G.; Heuvel, E.G.V.D.; Voragen, A.G.; Gruppen, H. Oligosaccharides in feces of breast- and formula-fed babies. Carbohydr. Res. 2011, 346, 2173-2181. [CrossRef] [PubMed]

206. Wang, M.; Li, M.; Wu, S.; Lebrilla, C.B.; Chapkin, R.S.; Ivanov, I.; Donovan, S.M. Fecal Microbiota Composition of Breast-Fed Infants Is Correlated With Human Milk Oligosaccharides Consumed. J. Pediatr. Gastroenterol. Nutr. 2015, 60, 825-833. [CrossRef]

207. Borewicz, K.; Gu, F.; Saccenti, E.; Hechler, C.; Beijers, R.; De Weerth, C.; Van Leeuwen, S.S.; Schols, H.A.; Smidt, H. The association between breastmilk oligosaccharides and faecal microbiota in healthy breastfed infants at two, six, and twelve weeks of age. Sci. Rep. 2020, 10, 1-12. [CrossRef]

208. Bruggencate, S.J.M.T.; Bovee-Oudenhoven, I.M.J.; Feitsma, A.L.; Van Hoffen, E.; Schoterman, M.H.C. Functional role and mechanisms of sialyllactose and other sialylated milk oligosaccharides. Nutr. Rev. 2014, 72, 377-389. [CrossRef]

209. Vázquez, E.; Barranco, A.; Ramírez, M.; Gruart, A.; Delgado-García, J.M.; Martínez-Lara, E.; Blanco, S.; Martín, M.J.; Castanys, E.; Buck, R.; et al. Effects of a human milk oligosaccharide, $2^{\prime}$-fucosyllactose, on hippocampal long-term potentiation and learning capabilities in rodents. J. Nutr. Biochem. 2015, 26, 455-465. [CrossRef]

210. Oliveros, E.; Ramirez, M.; Vazquez, E.; Barranco, A.; Gruart, A.; Delgado-Garcia, J.M.; Buck, R.; Rueda, R.; Martin, M.J. Oral supplementation of $2^{\prime}$-fucosyllactose during lactation improves memory and learning in rats. J. Nutr. Biochem. 2016, 31, 20-27. [CrossRef]

211. Fleming, S.A.; Mudd, A.T.; Hauser, J.; Yan, J.; Metairon, S.; Steiner, P.; Donovan, S.M.; Dilger, R.N. Human and Bovine Milk Oligosaccharides Elicit Improved Recognition Memory Concurrent With Alterations in Regional Brain Volumes and Hippocampal mRNA Expression. Front. Neurosci. 2020, 14, 770. [CrossRef]

212. Wang, B.; Brand-Miller, J.; McVeagh, P.; Petocz, P. Concentration and distribution of sialic acid in human milk and infant formulas. Am. J. Clin. Nutr. 2001, 74, 5-510. [CrossRef] [PubMed]

213. Lis-Kuberka, J.; Orczyk-Pawiłowicz, M. Sialylated Oligosaccharides and Glycoconjugates of Human Milk. The Impact on Infant and Newborn Protection, Development and Well-Being. Nutrients 2019, 11, 306. [CrossRef] [PubMed]

214. Wang, B.; Yu, B.; Karim, M.; Hu, H.; Sun, Y.; McGreevy, P.; Petocz, P.; Held, S.; Brandmiller, J.C. Dietary sialic acid supplementation improves learning and memory in piglets. Am. J. Clin. Nutr. 2007, 85, 561-569. [CrossRef] [PubMed] 
215. Jacobi, S.K.; Yatsunenko, T.; Li, D.; Dasgupta, S.; Yu, R.K.; Berg, B.M.; Chichlowski, M.; Odle, J. Dietary Isomers of Sialyllactose Increase Ganglioside Sialic Acid Concentrations in the Corpus Callosum and Cerebellum and Modulate the Colonic Microbiota of Formula-Fed Piglets. J. Nutr. 2016, 146, 200-208. [CrossRef] [PubMed]

216. Obelitz-Ryom, K.; Bering, S.B.; Overgaard, S.H.; Eskildsen, S.F.; Ringgaard, S.; Olesen, J.L.; Skovgaard, K.; Pankratova, S.; Wang, B.; Brunse, A.; et al. Bovine Milk Oligosaccharides with Sialyllactose Improves Cognition in Preterm Pigs. Nutrients 2019, 11, 1335. [CrossRef] [PubMed]

217. Mudd, A.T.; Fleming, S.A.; Labhart, B.; Chichlowski, M.; Berg, B.M.; Donovan, S.M.; Dilger, R.N. Dietary Sialyllactose Influences Sialic Acid Concentrations in the Prefrontal Cortex and Magnetic Resonance Imaging Measures in Corpus Callosum of Young Pigs. Nutrients 2017, 9, 1297. [CrossRef]

218. Oliveros, E.; Vázquez, E.; Barranco, A.; Ramirez, M.; Gruart, A.; Delgado-García, J.M.; Buck, R.; Rueda, R.; Martín, M.J. Sialic Acid and Sialylated Oligosaccharide Supplementation during Lactation Improves Learning and Memory in Rats. Nutrients 2018, 10, 1519. [CrossRef]

219. Charbonneau, M.R.; O’Donnell, D.; Blanton, L.V.; Totten, S.M.; Davis, J.C.C.; Barratt, M.J.; Cheng, J.; Guruge, J.; Talcott, M.; Bain, J.R.; et al. Sialylated Milk Oligosaccharides Promote Microbiota-Dependent Growth in Models of Infant Undernutrition. Cell 2016, 164, 859-871. [CrossRef]

220. Tarr, A.J.; Galley, J.D.; Fisher, S.E.; Chichlowski, M.; Berg, B.M.; Bailey, M.T. The prebiotics 3'Sialyllactose and 6'Sialyllactose diminish stressor-induced anxiety-like behavior and colonic microbiota alterations: Evidence for effects on the gut-brain axis. Brain Behav. Immun. 2015, 50, 166-177. [CrossRef]

221. Roger, L.C.; Costabile, A.; Holland, D.T.; Hoyles, L.; McCartney, A.L. Examination of faecal Bifidobacterium populations in breastand formula-fed infants during the first 18 months of life. Microbiology 2010, 156, 3329-3341. [CrossRef]

222. Soto, A.; Martín, V.; Jiménez, E.; Mader, I.; Rodríguez, J.M.; Fernández, L. Lactobacilli and Bifidobacteria in Human Breast Milk: Influence of Antibiotherapy and Other Host and Clinical Factors. J. Pediatr. Gastroenterol. Nutr. 2014, 59, 78-88. [CrossRef] [PubMed]

223. Stewart, C.J.; Ajami, N.J.; O’Brien, J.L.; Hutchinson, D.S.; Smith, D.; Wong, M.C.; Ross, M.C.; Lloyd, R.E.; Doddapaneni, H.; Metcalf, G.A.; et al. Temporal development of the gut microbiome in early childhood from the TEDDY study. Nat. Cell Biol. 2018, 562, 583-588. [CrossRef] [PubMed]

224. Ma, J.; Li, Z.; Zhang, W.; Zhang, C.; Zhang, Y.; Mei, H.; Zhuo, N.; Wang, H.; Wang, L.; Wu, D. Comparison of gut microbiota in exclusively breast-fed and formula-fed babies: A study of 91 term infants. Sci. Rep. 2020, 10, 15792. [CrossRef]

225. Hunt, K.M.; Foster, J.A.; Forney, L.J.; Schütte, U.M.E.; Beck, D.L.; Abdo, Z.; Fox, L.K.; Williams, J.E.; McGuire, M.K.; McGuire, M.A. Characterization of the Diversity and Temporal Stability of Bacterial Communities in Human Milk. PLoS ONE 2011, 6, e21313. [CrossRef] [PubMed]

226. Geddes, D.T.; Kent, J.C.; Owens, R.A.; Hartmann, P.E. Ultrasound Imaging of Milk Ejection in the Breast of Lactating Women. Pediatrics 2004, 113, 361-367. [CrossRef]

227. Perez, P.F.; Doré, J.; Leclerc, M.; Levenez, F.; Benyacoub, J.; Serrant, P.; Segura-Roggero, I.; Schiffrin, E.J.; Donnet-Hughes, A. Bacterial Imprinting of the Neonatal Immune System: Lessons From Maternal Cells? Pediatr. 2007, 119, e724-e732. [CrossRef]

228. Donnet-Hughes, A.; Perez, P.F.; Doré, J.; Leclerc, M.; Levenez, F.; Benyacoub, J.; Serrant, P.; Segura-Roggero, I.; Schiffrin, E.J. Potential role of the intestinal microbiota of the mother in neonatal immune education. Proc. Nutr. Soc. 2010, 69, 407-415. [CrossRef]

229. Turroni, F.; Peano, C.; Pass, D.A.; Foroni, E.; Severgnini, M.; Claesson, M.J.; Kerr, C.; Hourihane, J.; Murray, D.; Fuligni, F.; et al. Diversity of Bifidobacteria within the Infant Gut Microbiota. PLoS ONE 2012, 7, e36957. [CrossRef]

230. Moossavi, S.; Sepehri, S.; Robertson, B.; Bode, L.; Goruk, S.; Field, C.J.; Lix, L.M.; De Souza, R.J.; Becker, A.B.; Mandhane, P.J.; et al. Composition and Variation of the Human Milk Microbiota Are Influenced by Maternal and Early-Life Factors. Cell Host Microbe 2019, 25, 324-335.e324. [CrossRef]

231. Moschen, A.R.; Wieser, V.; Tilg, H. Dietary Factors: Major Regulators of the Gut's Microbiota. Gut Liver 2012, 6, 411-416. [CrossRef]

232. Shively, C.A.; Register, T.C.; Appt, S.E.; Clarkson, T.B.; Uberseder, B.; Clear, K.Y.; Wilson, A.S.; Chiba, A.; Tooze, J.A.; Cook, K.L. Consumption of Mediterranean versus Western Diet Leads to Distinct Mammary Gland Microbiome Populations. Cell Rep. 2018, 25, 47-56.e3. [CrossRef] [PubMed]

233. Lyons, K.E.; Ryan, C.A.; Dempsey, E.M.; Ross, R.P.; Stanton, C. Breast Milk, a Source of Beneficial Microbes and Associated Benefits for Infant Health. Nutrients 2020, 12, 1039. [CrossRef] [PubMed]

234. WHO. Guideline: Protecting, Promoting and Supporting Breastfeeding in Facilities Providing Maternity and Newborn Services; World Health Organization: Geneva, Switzerland, 2017; 120p.

235. Koletzko, B.; Von Kries, R.; Monasterolo, R.C.; Subías, J.E.; Scaglioni, S.; Giovannini, M.; Beyer, J.; Demmelmair, H.; Anton, B.; Gruszfeld, D.; et al. Can infant feeding choices modulate later obesity risk? Am. J. Clin. Nutr. 2009, 89, 1502S-1508S. [CrossRef] [PubMed]

236. Donovan, S.M. The Role of Lactoferrin in Gastrointestinal and Immune Development and Function: A Preclinical Perspective. J. Pediatr. 2016, 173, S16-S28. [CrossRef] [PubMed] 
237. Escribano, J.; Luque, V.; Ferré, N.; Mendez-Riera, G.; Koletzko, B.; Grote, V.; Demmelmair, H.; Bluck, L.; Wright, A.; Closa-Monasterolo, R.; et al. Effect of protein intake and weight gain velocity on body fat mass at 6 months of age: The EU Childhood Obesity Programme. Int. J. Obes. 2012, 36, 548-553. [CrossRef]

238. Ailhaud, G.P.; Massiera, F.; Weill, P.; Legrand, P.; Alessandri, J.-M.; Guesnet, P. Temporal changes in dietary fats: Role of $\mathrm{n}-6$ polyunsaturated fatty acids in excessive adipose tissue development and relationship to obesity. Prog. Lipid Res. 2006, 45, 203-236. [CrossRef]

239. Oosting, A.; Kegler, D.; Wopereis, H.J.; Teller, I.C.; Van De Heijning, B.J.M.; Verkade, H.J.; Van Der Beek, E.M. Size and phospholipid coating of lipid droplets in the diet of young mice modify body fat accumulation in adulthood. Pediatr. Res. 2012, 72, 362-369. [CrossRef]

240. Lasekan, J.; Jacobs, J.; Reisinger, K.S.; Montalto, M.B.; Frantz, M.P.; Blatter, M.M. Lactose-Free Milk Protein-Based Infant Formula: Impact on Growth and Gastrointestinal Tolerance in Infants. Clin. Pediatr. 2011, 50, 330-337. [CrossRef]

241. Einerhand, A. Infant formula brought closer to breast milk thanks to prebiotic oligosaccharides. Agro Food Ind. Hi-Tech 2016, 27, 20-24.

242. Chichlowski, M.; German, J.B.; Lebrilla, C.B.; Mills, D.A. The Influence of Milk Oligosaccharides on Microbiota of Infants: Opportunities for Formulas. Annu. Rev. Food Sci. Technol. 2011, 2, 331-351. [CrossRef]

243. Vandenplas, Y.; Berger, B.; Carnielli, V.P.; Książyk, J.; Lagström, H.; Sánchez-Luna, M.; Migacheva, N.B.; Mosselmans, J.-M.; Picaud, J.-C.; Possner, M.; et al. Human Milk Oligosaccharides: 2'-Fucosyllactose (2'-FL) and Lacto-N-Neotetraose (LNnT) in Infant Formula. Nutrients 2018, 10, 1161. [CrossRef] [PubMed]

244. Mugambi, M.N.; Musekiwa, A.; Lombard, M.; Young, T.; Blaauw, R. Synbiotics, probiotics or prebiotics in infant formula for full term infants: A systematic review. Nutr. J. 2012, 11, 81. [CrossRef] [PubMed]

245. Davis, E.C.; Dinsmoor, A.M.; Wang, M.; Donovan, S.M. Microbiome Composition in Pediatric Populations from Birth to Adolescence: Impact of Diet and Prebiotic and Probiotic Interventions. Dig. Dis. Sci. 2020, 65, 706-722. [CrossRef] [PubMed]

246. Moro, G.E.; Stahl, B.; Fanaro, S.; Jelinek, J.; Boehm, G.; Coppa, G.V. Dietary prebiotic oligosaccharides are detectable in the faeces of formula-fed infants. Acta Paediatr. 2005, 94, 27-30. [CrossRef] [PubMed]

247. Ben, X.-M.; Li, J.; Feng, Z.-T.; Shi, S.-Y.; Lu, Y.-D.; Chen, R.; Zhou, X.-Y. Low level of galacto-oligosaccharide in infant formula stimulates growth of intestinal Bifidobacteria and Lactobacilli. World J. Gastroenterol. 2008, 14, 6564-6568. [CrossRef]

248. Scholtens, P.A.M.J.; Alliet, P.; Raes, M.; Alles, M.S.; Kroes, H.; Boehm, G.; Knippels, L.M.J.; Knol, J.; Vandenplas, Y. Fecal Secretory Immunoglobulin A Is Increased in Healthy Infants Who Receive a Formula with Short-Chain Galacto-Oligosaccharides and Long-Chain Fructo-Oligosaccharides. J. Nutr. 2008, 138, 1141-1147. [CrossRef] [PubMed]

249. Maldonado, J. Probiotics and Prebiotics in Infant Formulae. Prebiotics Probiotics Potential Benefits Nutr. Health 2019. [CrossRef]

250. Lee, L.Y.; Bharani, R.; Biswas, A.; Lee, J.; Tran, L.-A.; Pecquet, S.; Steenhout, P. Normal growth of infants receiving an infant formula containing Lactobacillus reuteri, galacto-oligosaccharides, and fructo-oligosaccharide: A randomized controlled trial. Matern. Health Neonatol. Perinatol. 2015, 1, 1-10. [CrossRef]

251. Simeoni, U.; Berger, B.; Junick, J.; Blaut, M.; Pecquet, S.; Rezzonico, E.; Grathwohl, D.; Sprenger, N.; Brüssow, H.; Szajewska, H.; et al. Gut microbiota analysis reveals a marked shift to bifidobacteria by a starter infant formula containing a synbiotic of bovine milk-derived oligosaccharides and Bifidobacterium animalis subsp. lactis CNCM I -3446. Environ. Microbiol. 2016, 18, $2185-2195$. [CrossRef]

252. Szajewska, H.; Ruszczyński, M.; Szymanski, H.; Sadowska-Krawczenko, I.; Piwowarczyk, A.; Rasmussen, P.B.; Kristensen, M.B.; E West, C.; Hernell, O. Effects of infant formula supplemented with prebiotics compared with synbiotics on growth up to the age of 12 mo: A randomized controlled trial. Pediatr. Res. 2017, 81, 752-758. [CrossRef]

253. Panigrahi, P.; Parida, S.; Sailajanandan, P.; Satpathy, R.; Pradhan, L.; Chandel, D.S.; Baccaglini, L.; Mohapatra, A.; Mohapatra, S.S.; Misra, P.R.; et al. A randomized synbiotic trial to prevent sepsis among infants in rural India. Nat. Cell Biol. 2017, 548, 407-412. [CrossRef] [PubMed]

254. Manco, M.; Alterio, A.; Bugianesi, E.; Ciampalini, P.; Mariani, P.; Finocchi, M.; Agostoni, C.; Nobili, V. Insulin Dynamics of Breastor Formula-Fed Overweight and Obese Children. J. Am. Coll. Nutr. 2011, 30, 29-38. [CrossRef] [PubMed]

255. Socha, P.; Grote, V.; Gruszfeld, D.; Janas, R.; Demmelmair, H.; Closa-Monasterolo, R.; Subias, J.E.; Scaglioni, S.; Verduci, E.; Dain, E.; et al. Milk protein intake, the metabolic-endocrine response, and growth in infancy: Data from a randomized clinical trial. Am. J. Clin. Nutr. 2011, 94, 1776S-1784S. [CrossRef] [PubMed]

256. Rzehak, P.; Oddy, W.H.; Mearin, M.L.; Grote, V.; Mori, T.A.; Szajewska, H.; Shamir, R.; Koletzko, S.; Weber, M.; Beilin, L.J.; et al. Infant feeding and growth trajectory patterns in childhood and body composition in young adulthood. Am. J. Clin. Nutr. 2017, 106, 568-580. [CrossRef]

257. Alvisi, P.; Brusa, S.; Alboresi, S.; Amarri, S.; Bottau, P.; Cavagni, G.; Corradini, B.; Landi, L.; Loroni, L.; Marani, M.; et al. Recommendations on complementary feeding for healthy, full-term infants. Ital. J. Pediatr. 2015, 41, 36. [CrossRef]

258. Laursen, M.F.; Bahl, M.I.; Michaelsen, K.F.; Licht, T.R. First Foods and Gut Microbes. Front. Microbiol. 2017, 8, 356. [CrossRef]

259. Bäckhed, F.; Roswall, J.; Peng, Y.; Feng, Q.; Jia, H.; Kovatcheva-Datchary, P.; Li, Y.; Xia, Y.; Xie, H.; Zhong, H.; et al. Dynamics and Stabilization of the Human Gut Microbiome during the First Year of Life. Cell Host Microbe 2015, 17, 690-703. [CrossRef]

260. Luczynski, P.; Whelan, S.O.; O’Sullivan, C.; Clarke, G.; Shanahan, F.; Dinan, T.G.; Cryan, J.F. Adult microbiota-deficient mice have distinct dendritic morphological changes: Differential effects in the amygdala and hippocampus. Eur. J. Neurosci. 2016, 44, 2654-2666. [CrossRef] 
261. Nicklaus, S.; Remy, E. Early Origins of Overeating: Tracking Between Early Food Habits and Later Eating Patterns. Curr. Obes. Rep. 2013, 2, 179-184. [CrossRef]

262. Johnson, E.W.; Eller, P.; Jafek, B. Distribution of OMP-, PGP 9.5 and CaBP-like immunoreactive chemoreceptor neurons in the developing human olfactory epithelium. Anat. Embryol. 2004, 191, 311-317. [CrossRef]

263. Lipchock, S.V.; Reed, D.R.; Mennella, J.A. The Gustatory and Olfactory Systems During Infancy: Implications for Development of Feeding Behaviors in the High-Risk Neonate. Clin. Perinatol. 2011, 38, 627-641. [CrossRef] [PubMed]

264. Goran, M.I.; Plows, J.F.; Ventura, E.E. Effects of consuming sugars and alternative sweeteners during pregnancy on maternal and child health: Evidence for a secondhand sugar effect. Proc. Nutr. Soc. 2019, 78, 262-271. [CrossRef] [PubMed]

265. Popkin, B.M.; Corvalan, C.; Grummer-Strawn, L.M. Dynamics of the double burden of malnutrition and the changing nutrition reality. Lancet 2020, 395, 65-74. [CrossRef]

266. Dörsam, A.F.; Preissl, H.; Micali, N.; Lörcher, S.B.; Zipfel, S.; Giel, K. The Impact of Maternal Eating Disorders on Dietary Intake and Eating Patterns during Pregnancy: A Systematic Review. Nutrients 2019, 11, 840. [CrossRef]

267. Yan, X.; Zhao, X.; Li, J.; He, L.; Xu, M. Effects of early-life malnutrition on neurodevelopment and neuropsychiatric disorders and the potential mechanisms. Prog. Neuro-Psychopharmacol. Biol. Psychiatry 2018, 83, 64-75. [CrossRef]

268. Wells, J.C.K. The capacity-load model of non-communicable disease risk: Understanding the effects of child malnutrition, ethnicity and the social determinants of health. Eur. J. Clin. Nutr. 2018, 72, 688-697. [CrossRef]

269. Ozkale, M.; Sipahi, T. Hematologic and Bone Marrow Changes in Children with Protein-Energy Malnutrition. Pediatr. Hematol. Oncol. 2013, 31, 349-358. [CrossRef]

270. Rytter, M.J.H.; Kolte, L.; Briend, A.; Friis, H.; Christensen, V.B. The Immune System in Children with Malnutrition—A Systematic Review. PLoS ONE 2014, 9, e105017. [CrossRef] [PubMed]

271. Belkacemi, L.; Nelson, D.M.; Desai, M.; Ross, M.G. Maternal Undernutrition Influences Placental-Fetal Development. Biol. Reprod. 2010, 83, 325-331. [CrossRef] [PubMed]

272. Million, M.; Diallo, A.; Raoult, D. Gut microbiota and malnutrition. Microb. Pathog. 2017, 106, 127-138. [CrossRef] [PubMed]

273. Antonow-Schlorke, I.; Schwab, M.; Cox, L.A.; Li, C.; Stuchlik, K.; Witte, O.W.; Nathanielsz, P.W.; McDonald, T.J. Vulnerability of the fetal primate brain to moderate reduction in maternal global nutrient availability. Proc. Natl. Acad. Sci. USA 2011, 108, 3011-3016. [CrossRef] [PubMed]

274. Marín, M.C.; De Tomás, M.E.; Serres, C.; Mercuri, O. Protein-energy malnutrition during gestation and lactation in rats affects growth rate, brain development and essential fatty acid metabolism. J. Nutr. 1995, 125, 1017-1024. [PubMed]

275. Wang, L.; Xu, R.-J. The effects of perinatal protein malnutrition on spatial learning and memory behaviour and brain-derived neurotrophic factor concentration in the brain tissue in young rats. Asia Pac. J. Clin. Nutr. 2007, 16 (Suppl. 1.), 467-472. [PubMed]

276. Scrimshaw, N.S. Malnutrition, brain development, learning, and behavior. Nutr. Res. 1998, 18, 351-379. [CrossRef]

277. De Souza, A.S.; Spreafico, F.; Carmo, M.D.G.T.D. Effects of maternal malnutrition and postnatal nutritional rehabilitation on brain fatty acids, learning, and memory. Nutr. Rev. 2011, 69, 132-144. [CrossRef] [PubMed]

278. Prado, E.L.; Dewey, K.G. Nutrition and brain development in early life. Nutr. Rev. 2014, 72, 267-284. [CrossRef]

279. Hashimoto, T.; Perlot, T.; Rehman, A.; Trichereau, J.; Ishiguro, H.; Paolino, M.; Sigl, V.; Hanada, T.; Hanada, R.; Lipinski, S.; et al. ACE2 links amino acid malnutrition to microbial ecology and intestinal inflammation. Nat. Cell Biol. 2012, 487, 477-481. [CrossRef] [PubMed]

280. Smythe, P. Changes in intestinal bacterial flora and role of infection in kwashiorkor. Lancet 1958, 272, 724-727. [CrossRef]

281. Subramanian, S.; Huq, S.; Yatsunenko, T.; Haque, R.; Mahfuz, M.; Alam, M.A.; Benezra, A.; DeStefano, J.; Meier, M.F.; Muegge, B.D.; et al. Persistent gut microbiota immaturity in malnourished Bangladeshi children. Nature 2014, 510, 417-421. [CrossRef]

282. Blanton, L.V.; Barratt, M.J.; Charbonneau, M.R.; Ahmed, T.; Gordon, J.I. Childhood undernutrition, the gut microbiota, and microbiota-directed therapeutics. Science 2016, 352, 1533. [CrossRef]

283. Gehrig, J.L.; Venkatesh, S.; Chang, H.-W.; Hibberd, M.C.; Kung, V.L.; Cheng, J.; Chen, R.Y.; Subramanian, S.; Cowardin, C.A.; Meier, M.F.; et al. Effects of microbiota-directed foods in gnotobiotic animals and undernourished children. Science 2019, 365, eaau4732. [CrossRef] [PubMed]

284. Kane, A.V.; Dinh, D.M.; Ward, H.D. Childhood malnutrition and the intestinal microbiome. Pediatr. Res. 2015, 77, $256-262$. [CrossRef] [PubMed]

285. Golden, M.H.N.; Ramdath, D. Free Radicals in the Pathogenesis of Kwashiorkor. Proc. Nutr. Soc. 1987, 46, 53-68. [CrossRef] [PubMed] 